\title{
Perspectives for improvement of Mycoplasma hyopneumoniae vaccines in pigs
}

\author{
Dominiek Maes $^{1^{*}} \mathbb{D}$, Filip Boyen ${ }^{1}$, Bert Devriendt ${ }^{1}$, Peter Kuhnert ${ }^{2}$, Artur Summerfield ${ }^{3,4}$ and \\ Freddy Haesebrouck ${ }^{1}$
}

\begin{abstract}
Mycoplasma hyopneumoniae (M. hyopneumoniae) is one of the primary agents involved in the porcine respiratory disease complex, economically one of the most important diseases in pigs worldwide. The pathogen adheres to the ciliated epithelium of the trachea, bronchi, and bronchioles, causes damage to the mucosal clearance system, modulates the immune system and renders the animal more susceptible to other respiratory infections. The pathogenesis is very complex and not yet fully understood. Cell-mediated and likely also mucosal humoral responses are considered important for protection, although infected animals are not able to rapidly clear the pathogen from the respiratory tract. Vaccination is frequently practiced worldwide to control $M$. hyopneumoniae infections and the associated performance losses, animal welfare issues, and treatment costs. Commercial vaccines are mostly bacterins that are administered intramuscularly. However, the commercial vaccines provide only partial protection, they do not prevent infection and have a limited effect on transmission. Therefore, there is a need for novel vaccines that confer a better protection. The present paper gives a short overview of the pathogenesis and immune responses following M. hyopneumoniae infection, outlines the major limitations of the commercial vaccines and reviews the different experimental M. hyopneumoniae vaccines that have been developed and tested in mice and pigs. Most experimental subunit, DNA and vector vaccines are based on the P97 adhesin or other factors that are important for pathogen survival and pathogenesis. Other studies focused on bacterins combined with novel adjuvants. Very few efforts have been directed towards the development of attenuated vaccines, although such vaccines may have great potential. As cell-mediated and likely also humoral mucosal responses are important for protection, new vaccines should aim to target these arms of the immune response. The selection of proper antigens, administration route and type of adjuvant and carrier molecule is essential for success. Also practical aspects, such as cost of the vaccine, ease of production, transport and administration, and possible combination with vaccines against other porcine pathogens, are important. Possible avenues for further research to develop better vaccines and to achieve a more sustainable control of M. hyopneumoniae infections are discussed.
\end{abstract}

Keywords: Mycoplasma hyopneumoniae, Vaccination, Immune responses, Experimental vaccines, Pig

Table of Contents

1 Introduction

2 Interactions of M. hyopneumoniae with the host

2.1 The organism

*Correspondence: Dominiek.Maes@UGent.be

${ }^{1}$ Faculty of Veterinary Medicine, Ghent University, Merelbeke, Belgium

Full list of author information is available at the end of the article

\subsection{Adherence}

2.3 Virulence factors

2.4 Immune responses

2.4.1 Innate immune responses

2.4.2 Humoral responses

2.4.3 Cell-mediated responses

3 Commercial vaccines against M. hyopneumoniae

3.1 Type of vaccines

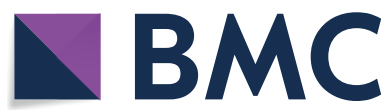

(C) The Author(s) 2021. This article is licensed under a Creative Commons Attribution 4.0

International License, which permits use, sharing, adaptation, distribution and reproduction in any medium or format, as long as you give appropriate credit to the original author(s) and the source, provide a link to the Creative Commons licence, and indicate if changes were made. The images or other third party material in this article are included in the article's Creative Commons licence, unless indicated otherwise in a credit line to the material. If material is not included in the article's Creative Commons licence and your intended use is not permitted by statutory regulation or exceeds the permitted use, you will need to obtain permission directly from the copyright holder. To view a copy of this licence, visit http://creativecommons.org/licenses/by/4.0/. The Creative Commons Public Domain Dedication waiver (http://creativecommons.org/publicdomain/zero/1.0/) applies to the data made available in this article, unless otherwise stated in a credit line to the data. 
3.2 Mechanisms of protection upon vaccination

3.3 Efficacy of commercial vaccines

4 Experimental vaccines

4.1 Experimental vaccines studied in mice

4.2 Experimental vaccines studied in pigs

5 Avenues for further research

5.1 Administration route

5.2 Antigen

5.3 Adjuvant and carrier

5.4 Attenuated vaccines

6 Conclusions

References

\section{Introduction}

Mycoplasma hyopneumoniae (M. hyopneumoniae) is the most important Mycoplasma sp. in swine health management. It is the primary pathogen of enzootic pneumonia, a chronic respiratory disease in pigs, and one of the primary agents involved in the porcine respiratory disease complex [1]. Infections with $M$. hyopneumoniae are highly prevalent in almost all swine producing areas, and they cause significant economic losses due to increased medication use and decreased performance of the pigs [2].

Similar to other mycoplasmas, M. hyopneumoniae lacks a cell wall. The organism is very difficult to isolate because of its slow growth and potential overgrowth with other swine mycoplasmas. The pathogen-host interactions are very complex and not fully characterized. The organism is primarily identified on the mucosal surface of the trachea, bronchi, and bronchioles [3]. It affects the mucosal clearance system by disrupting the cilia on the epithelial surface and, additionally, the organism modulates the immune system of the respiratory tract [4]. Therefore, M. hyopneumoniae predisposes animals to concurrent infections with other respiratory pathogens.

Control of M. hyopneumoniae infections in pig herds can be accomplished by optimizing management, housing and biosecurity practices [5]. Treatment can be done using medication with antimicrobials active against $M$. hyopneumoniae. Antimicrobial medication can limit the consequences of the disease and decrease the infection load [6], but it does not prevent pigs from becoming infected with $M$. hyopneumoniae. Medication with antimicrobials is also discouraged because of the risk of antimicrobial resistance development [7]. Vaccination against $M$. hyopneumoniae has been shown to be a useful tool to control M. hyopneumoniae infections. Different inactivated, whole-cell vaccines are commercially available and vaccination is frequently practiced worldwide. In infected herds, vaccination decreases clinical signs and lung lesions due to M. hyopneumoniae infections, performance losses of the animals and antimicrobial use. Although the commercial vaccines are widely used and cost-efficient in many farms, they induce only a partial protection and do not prevent infection.

The present paper discusses the complex interaction of M. hyopneumoniae with the host and the limitations of the currently available commercial vaccines. Next, the different experimental vaccines that have been developed and tested in mice and pigs are reviewed. Finally, avenues for further research are provided in order to improve $M$. hyopneumoniae vaccination and achieve a more sustainable control of M. hyopneumoniae infections.

\section{Interactions of $M$. hyopneumoniae with the host}

\subsection{The organism}

$M$. hyopneumoniae is a small $(0.2-0.4 \mu \mathrm{m})$ and pleomorphic organism as it lacks a shape-defining cell-wall. Studies have shown a high diversity at genomic, antigenic, and proteomic level between different strains [8]. The genomes of the earliest described M. hyopneumoniae strains (the pathogenic strains 232 and 7448, and the nonpathogenic strain J) were sequenced in 2004 [9, 10]. Since then, the genomes of several other strains have been sequenced. Currently, 23 entirely sequenced M. hyopneumoniae genomes are available, 11 already assembled and annotated, and 12 not fully assembled. In general, the genomes are small in size, namely $0.86-0.96 \mathrm{Mb}$, and in each of them, there are 528 to 691 protein-encoding genes [11]. Despite the small genome, up to $30 \%$ of the gene content is still of unknown function [12]. In addition, 20 to $30 \%$ of the M. hyopneumoniae genes encode surface proteins, the function of many of them is not yet known [12]. The mean GC content, which influences genome organization and gene expression, is low (28.54\%) compared to other bacterial species. The low GC content gives M. hyopneumoniae a complex transcriptional organization, unique intrinsic terminator stem-loop formation and individual ribonuclease $\mathrm{P}$ (RNase P) structure [13].

The small genome of $M$. hyopneumoniae and the limited number of secreted or surface proteins is particularly interesting for use of recombinant DNA technology. However, M. hyopneumoniae uses an unusual genetic code. The amino acid tryptophan is not encoded by TGG, but by TGA, which is a stop codon in most organisms [14]. This difference has hampered the expression of genes of $M$. hyopneumoniae containing TGA codons in $E$. coli, the most attractive system used for production of recombinant proteins. However, mutations replacing TGA codons with TGG have been used successfully to solve this problem [15]. 


\subsection{Adherence}

Upon inhalation, M. hyopneumoniae adheres to the ciliated epithelial cells of the trachea, bronchi and bronchioles underneath the mucous layer. Adhesion is followed by the induction of ciliostasis, loss of cilia, and eventually epithelial cell death [16].

A repertoire of at least $35 \mathrm{M}$. hyopneumoniae proteins have been associated with cell adhesion, including several related to the P97/P102 paralog families and other surface proteins that moonlight as adhesins [17, 18]. The number of $M$. hyopneumoniae adhesins can even be higher, considering that its surfaceome includes more than 290 proteins and that many uncharacterized surface displayed proteins may bear adhesion properties. Different adhesins may vary in abundance at the cell surface between strains. This may be due to differential transcriptional rates of the respective genes, differential translational rates of the corresponding mRNAs and/or post-translational events, including their export to the cell membrane and proteolytic processing. Proteolytic processing of adhesins can shape the bacterial surface architecture [19], generating several adhesin proteoforms, that may exert alternative functions. Some of them are displayed at the cell surface, while others may stay in the cytoplasm or be released from the cell membrane to the extracellular milieu [11].

P97 is one of the most important adhesins of M. hyopneumoniae and also the most intensively studied one, and therefore, it has been tested in many experimental vaccines. P97 contains two repeat regions (R1 and R2), located in the $\mathrm{C}$-terminal portion. The sites that are involved in cilium binding are located in the $\mathrm{R} 1$ region and at least seven AAKPV/E repeats are required for functional binding. Both R1 and R2 are involved in the attachment of $M$. hyopneumoniae to the extracellular matrix of the respiratory tract [20].

Apart from the cilia-exposed glycans, some swine extracellular matrix molecules, such as fibronectin and plasminogen, also provide binding sites for surface adhesins of $M$. hyopneumoniae [11]. The fibronectinand plasminogen-binding ability of M. hyopneumoniae may mediate subsequent adherence to swine respiratory cilia. Further research is needed to investigate whether adherence to fibronectin and plasminogen may facilitate internalization of $M$. hyopneumoniae and facilitate its traffic via the circulatory system and penetration into host organs, such as liver, kidneys and spleen [21]. The exact role of plasmin in the chronic inflammatory response as observed during $M$. hyopneumoniae infection is unclear, but it may influence the migration of inflammatory cells and stimulate the release of pro-inflammatory cytokines [22].
Extracellular actin is also used as a surface receptor by different proteoforms of M. hyopneumoniae P97 adhesin and other proteins, including lipoproteins, glycolytic enzymes, chaperones and translation factors [23]. Apart from extracellular actin, surface proteins of $M$. hyopneumoniae also interact with other cytoskeletal proteins, such as vimentin, keratin, tubulin, myosin, and tropomyosin [24].

\subsection{Virulence factors}

Adhesion serves as the starting point of infection which is then assisted by other virulence factors. Classical virulence factors like toxins are generally lacking in Mycoplasma species. Mycoplasma hyopneumoniae can produce $\mathrm{H}_{2} \mathrm{O}_{2}$ in the presence of glycerol in vitro. However, this is strain dependent and the attenuated type strain $\mathrm{J}$ does not produce detectable amounts of $\mathrm{H}_{2} \mathrm{O}_{2}$ [25]. Whether production of hydrogen peroxide should be considered as a possible in vivo virulence mechanism in $M$. hyopneumoniae remains to be investigated. Ferrarini et al. [25] showed that $M$. hyopneumoniae is able to take up myo-inositol and use it as an alternative energy source in the absence of glucose. Since myo-inositol is freely available in the serum of pigs, it might be a suitable alternative energy source for $M$. hyopneumoniae residing in the highly vascularized lungs.

Lipid associated membrane proteins (LAMP) have also been implicated in the pathogenicity of mycoplasmas. They interact with the host immune system mainly through Toll-like receptors (TLRs), such as TLR2 [26]. In M. hyopneumoniae, whole membrane lipoprotein fractions induced apoptosis in various cell types, including porcine peripheral blood mononuclear cells (PBMCs) [27]. Furthermore, LAMPs activate production of nitric oxide and reactive oxygen species in the host cell [28].

Mycoplasmas need to scavenge nutrients including nucleotides from their environment and therefore, they are well known for their potent membrane nucleases [14]. A well-recognized membrane nuclease is MnuA. Macrophages and neutrophils may form extracellular traps (METs or NETs, respectively), consisting of an interlacement of chromatin fibres rich in DNA, host defense proteins and enzymes, allowing immobilization and killing of invading microbes. In Mycoplasma bovis (M. bovis), MnuA was shown to degrade DNA-based neutrophil and macrophage extracellular traps (NETs and METs, respectively), thereby enabling $M$. bovis to escape these traps [29] and not being killed by these innate immune cells. The nuclease-encoding mnuA gene is also present in M. hyopneumoniae [30]. Therefore, MnuA could be a surface nuclease that is responsible for the degradation of NETs/METs, allowing M. hyopneumoniae to escape the host immune defense and using at the same time the 
nucleotides and protein synthesis materials as nutrients for proliferation [31].

Mycoplasma hyopneumoniae may release extracellular DNA that allows the organism to form biofilms on abiotic and host surfaces [32]. Biofilm formation makes the pathogen more resistant to antimicrobials and the host immune responses. The molecular interactions and cellular processes underlying $M$. hyopneumoniae biofilm formation are thus far mostly unknown.

In Mycoplasma genitalium, an immunoglobulin (Ig) G binding protein, called protein $\mathrm{M}$, has been identified. This protein not only fixes IgG very efficiently but also prevents subsequent antigen-antibody binding and subsequent signaling pathways of the bound antibodies [33]. In vitro experiments have shown that genes from $\mathrm{Myco-}$ plasma mycoides subspecies capri encode a Mycoplasma Ig binding protein (MIB) and a Mycoplasma Ig protease (MIP). The complex of MIB and Ig is necessary for the proteolytic activity of MIP. The two proteins are encoded by two genes and are often detected in multiple copies in various Mycoplasma sp., including M. hyopneumoniae [34]. Further studies are needed to investigate the role of the MIB-MIP system in virulence and immune evasion of M. hyopneumoniae.

Integrative and conjugative elements (ICE) are selftransmissible mobile genetic elements involved in horizontal gene transfer, thereby providing new virulence and/or antibiotic resistance traits. Such ICE have been identified in M. hyopneumoniae [35], but their role in encoding virulence traits of $M$. hyopneumoniae remains unclear.

Several large-scale comparisons on the genome, transcriptome, proteome, metabolome and secretome level have been performed in order to investigate virulence and pathogenesis of $M$. hyopneumoniae [24, 36]. Liu et al. reported that besides the known virulence-associated proteins (mainly adhesins), mutations were also found in genes involved in metabolism and growth [36]. $M$. hyopneumoniae is a genome-reduced organism that is characterized by a limited set of biosynthetic pathways, as such it is not surprising that further loss of enzymatic functions might have a large influence on survival and growth of the microorganism. This also holds true for lipoproteins involved in nutrient acquisition [37]. A comprehensive proteome profiling of two M. hyopneumoniae strains and $M$. flocculare provided tens of novel candidates to enzootic pneumonia determinants or virulence factors [24].

\subsection{Immune responses}

The interaction of the pathogen with the immune system of the host is not yet fully elucidated, and it is clear that some components of the immune system may both help and hinder the development of Mycoplasma-induced pneumonia $[17,38]$. Infection induces the production of pro-inflammatory (e.g. interleukin (IL)-1 $\beta$, IL-6, TNF- $\alpha$ ) and immunoregulatory (e.g. IL-10) cytokines by macrophages, neutrophils and lymphocytes in the lung. This excessive inflammatory response is associated with lymphoid hyperplasia and is considered to be a major driver of lung lesions [39].

\subsubsection{Innate immune responses}

It has been shown that Toll-like receptor 2 (TLR2) and TLR6 are important in the recognition of M. hyopneumoniae by porcine alveolar macrophages [40]. The activation of this signal pathway leads to the production of pro-inflammatory cytokines like TNF- $\alpha$, IL- $1 \beta$, and IL- 6 by alveolar macrophages. Blocking TLR2 and TLR6 receptors led to less TNF- $\alpha$ production by macrophages [41], indicating that alveolar macrophages are involved in inflammatory and innate immune responses during M. hyopneumoniae infection. M. hyopneumoniae was also demonstrated to strongly activate monocytes and $\mathrm{B}$ cells in vitro, with the $\mathrm{B}$ cell-activation resulting in a potent polyreactive antibody response [42]. Nevertheless, the role of these responses in protection against $M$. hyopneumoniae infection is still unknown. Also, it is not clear why there is a low neutrophil infiltration upon $M$. hyopneumoniae infection.

Recently, Mucha et al. [43] investigated changes in gene expression of swine epithelial cells of the trachea upon infection with $M$. hyopneumoniae. Among the up-regulated genes, they found several genes related to immune response and inflammation, such as $\mathrm{C} 3$ complement, $S A A 3$, chemokines (CXCL2 and CCL20) and galectins. These chemokines may attract myeloid cells. The study also suggested that ciliostasis caused by this pathogen might partially be explained by the down-regulation of ciliary genes. The innate immune responses against $M$. hyopneumoniae and mycoplasma in general have been reviewed in more detail elsewhere [4].

\subsubsection{Humoral responses}

After experimental infection, $M$. hyopneumoniae-specific serum IgG antibodies are detected 3-4 weeks post-infection (pi), peak after 11-12 weeks and then decrease very gradually [44]. After booster infection, serum antibody titers clearly increase and then slowly decline again [44]. Interestingly, pigs infected with a highly virulent strain appear to seroconvert earlier than pigs infected with a low virulent strain [45]. Mycoplasma hyopneumoniae-specific IgM in serum can be detected as early as 9 days pi under experimental conditions. The percentage of IgM positive pigs peaks at 14 days pi and rapidly decreases afterwards [46]. When infection occurs naturally, seroconversion is 
usually slower. Local M. hyopneumoniae-specific antibodies precede specific serum antibodies following infection but decline faster [47]. Mycoplasma hyopneumoniae-specific IgA can be detected in nasal swabs as early as 6 days pi, peak 12-16 days pi and decline steadily afterwards to reach pre-immune levels by day 84 pi.

Mycoplasma hyopneumoniae-specific IgG levels in serum induced by vaccination are not correlated with the severity of lung lesions in M. hyopneumoniae-infected pigs, suggesting that systemic antibodies play a minor role in protective immunity [48]. The role of mucosal antibodies in the protection against $M$. hyopneumoniae is still unclear. Some studies demonstrated that specific antibody levels in the respiratory tract did not correlate with protection $[48,49]$, whereas other studies emphasized the role of $M$. hyopneumoniae-specific secretory IgA in preventing adhesion of the microorganism to the ciliated cells of the respiratory tract [50-52]. Furthermore, specific IgG diffusing from the blood into the lung tissue or produced locally in the BALT could opsonize $M$. hyopneumoniae, resulting in phagocytosis by macrophages and neutrophils [53]. However, Deeney et al. [54] recently reported that addition of convalescent porcine sera did not enhance engulfment of M. hyopneumoniae by alveolar macrophages in vitro.

\subsubsection{Cell-mediated responses}

$\mathrm{T}$ cell-mediated immune responses are generally considered important for protection against Mycoplasmas causing local respiratory infections such as M. hyopneumoniae [4]. $\mathrm{T}$ cells are key in the regulation of immune responses and have a critical impact on the development of Mycoplasma-induced pneumonia [38]. Mycoplasma pulmonis challenge studies using various $\mathrm{T}$ cell subsetdepleted mice indicate that T helper 1 (Th1), Th17 and $\mathrm{CD}^{+} \mathrm{T}$ cell responses are responsible for protection against Mycoplasma disease. In contrast, Th2 responses are less efficient in controlling the infection and thus contribute to immunopathology [38]. In a M. hyopneumoniae vaccination-challenge study resulting in a significant reduction of lung lesions in the vaccinated group, Thacker et al. [50] observed a higher level of IFN- $\gamma$-secreting blood lymphocytes in vaccinated pigs compared to nonvaccinated ones before and after experimental infection. In $M$. hyopneumoniae-vaccination studies using a $M$. hyopneumoniae-resistant and a non-resistant pig line, higher serum levels of IFN- $\gamma$ and IL-17A, but lower levels of IL- 4 and CD4 ${ }^{+} \mathrm{T}$ cells were detected in the resistant line compared to the non-resistant line after vaccination [55]. As IFN- $\gamma$, IL-4 and IL-17A are the effector cytokines produced by Th1, Th2 and Th17 cells, respectively [4], these results support the findings obtained in mouse models that Th1 and Th17 responses are responsible for protection against Mycoplasma disease. Next to that, Marchioro et al. [53] found a lower $\mathrm{CD} 4^{+} / \mathrm{CD}^{+}$ratio, and thus a higher relative number of $\mathrm{CD}^{+}$cells in pigs vaccinated with a commercial $M$. hyopneumoniae bacterin compared to control pigs receiving a physiological saline solution. This supports the hypothesis that $\mathrm{CD}^{+}$ $\mathrm{T}$ cells have a protective role in Mycoplasma infections and could partially explain the beneficial effects observed after vaccination against $M$. hyopneumoniae.

$\mathrm{T}$ helper 1 responses may contribute to protection against Mycoplasma infections by IFN- $\gamma$-mediated activation of macrophage killing. It is now well-established that Th17 immune responses are important to protect mucosal surfaces, to promote epithelial cell regeneration, mucous and antimicrobial protein production, and the release of neutrophil recruitment [56]. Following a mycoplasma infection, Th17 cells could protect the lung mucosa by attracting other immune cells for pathogen clearance [57] and by elevating secretory IgA levels in the airway lumen [58]. The major characteristic of $\mathrm{CD}^{+}$cells is killing infected cells [59]. Since there is some evidence that $M$. hyopneumoniae is able to invade porcine epithelial cells [32], this characteristic of $\mathrm{CD}^{+}$cells might be relevant in the immune response against $M$. hyopneumoniae. Interestingly, studies performed in the $M$. pulmonis mouse model suggest that $\mathrm{CD}^{+} \mathrm{T}$ cells might dampen the pro-inflammatory Th cell responses responsible for lung damage and clinical disease [38]. It is suggested that IFN- $\gamma$-producing $\mathrm{CD}^{+} \mathrm{T}$ cells may skew the responses towards a protective Th1 response. Another possibility could be that $\mathrm{CD}^{+} \mathrm{T}$ cells kill antigen presenting cells (APCs), thus reducing the possibility of Th cell activation [38].

\section{Commercial vaccines against $M$. hyopneumoniae}

\subsection{Type of vaccines}

Commercial vaccines mostly consist of adjuvanted inactivated, whole-cell preparations (for an overview see Maes et al. [60]). Most vaccines are based on the strain J, possibly because it is the type strain of $M$. hyopneumoniae and grows easier in culture medium than recent field isolates. This strain was isolated in 1963 from a field outbreak of enzootic pneumonia in the UK. Commercial bacterin vaccines are licensed either for single or double vaccination, and combinations with porcine circovirus type 2 (PCV-2) or Glaesserella parasuis (formerly Haemophilus parasuis) are available. Most bacterin vaccines should be administered intramuscularly, but some bacterins are also licensed for intradermal administration. An inactivated vaccine based on soluble antigens of $M$. hyopneumoniae is also commercially available [61].

Attenuated vaccines against $M$. hyopneumoniae have been licensed in Mexico and in China [62]. The vaccine 
in Mexico is a thermosensitive mutant of M. hyopneumoniae (strain LKR) that should be applied intranasally [60]. The attenuated Chinese vaccine strain is derived from a virulent parent strain 168 isolated in 1974 from an Erhua-nian pig with enzootic pneumonia [63]. This field strain was gradually attenuated by continuous alternating passage through modified Friis medium and pigs. The attenuated strain contains 60 insertions and 43 deletions compared to the original wild type strain. Mutations in genes related to metabolism and growth may contribute to the attenuated virulence, in addition to variations previously described in $M$. hyopneumoniae adhesins (P97, P102, P146, P159, P216, and LppT), cell envelope proteins (P95), cell surface antigens (P36), and secreted proteins and chaperone protein (DnaK) [36]. The Chinese vaccine strain is mostly used by intrapulmonary administration [63]. Residual virulence and/or reversion to increased virulence might represent a risk in case of attenuated vaccines, although the Chinese vaccine has been used already for many years without reported side effects [60].

\subsection{Mechanisms of protection upon vaccination}

Commercial vaccines induce partial protection against M. hyopneumoniae infections. However, the immune mechanisms resulting in partial protection are not fully elucidated. Several studies observed lower levels of the pro-inflammatory cytokines associated with lymphoid hyperplasia and pneumonia lesions, such as TNF- $\alpha$, Il-6 and IL- $1 \beta$ in $M$. hyopneumoniae-vaccinated pigs compared to non-vaccinated ones [53, 64]. Moreover, vaccinated pigs had a higher number of IL-10-producing cells in their bronchial lymph nodes, which may have an anti-inflammatory effect [53]. Indeed, Vranckx et al. [65] demonstrated that vaccination reduces macrophage infiltration in the BALT of experimentally infected pigs. These findings suggest that vaccination modulates the infiltration of immune cells, as well as the secretion of pro- and anti-inflammatory cytokines, resulting in a reduction of lung lesions. Alternatively, it might also be possible that the reduced inflammatory responses is a consequence of a lower bacterial load [52].

The number of animals seroconverting after vaccination, as well as the antibody levels induced in serum and respiratory tract washings may vary depending on the vaccine composition, administration route, vaccination strategy (single or double vaccination) and the infection status of the animal [60]. The serological response upon a single vaccination is generally lower than after double vaccination. Serum antibodies are usually detected from two to 4 weeks after two-dose vaccination and they remain detectable for weeks to months. In the absence of natural infections that boost the immune system, antibody titers decrease below detection limits 1 to 3 months after vaccination [66]. Early studies indicate no correlation between vaccine-induced serum antibody levels and protection [67], but understanding the role of antibodies requires future investigations. Live-attenuated vaccines applied via the mucosal route could theoretically induce a local IgA response that could prevent colonization but to our knowledge, such data has not been reported.

Several studies found an increase in M. hyopneumoniae-specific IFN- $\gamma$-secreting cells in the blood and lung tissue of vaccinated animals [53, 64, 68]. These cells, characteristic for local and systemic Th1 responses, are considered to play an important role in vaccine-induced protection.

\subsection{Efficacy of commercial vaccines}

The major advantages of piglet vaccination relate to increased animal welfare and a decrease of the performance losses due to $M$. hyopneumoniae infections: improvement of daily weight gain $(2-8 \%)$, feed conversion ratio $(2-5 \%)$ and sometimes mortality rate. Additionally, shorter time to reach slaughter weight, less variation in slaughter weight (more homogeneous carcasses), reduced clinical signs (coughing), lower prevalence and severity of lesions typically caused by $M$. hyopneumoniae and lower treatment costs, are observed [69]. The currently used vaccines reduce the number of M. hyopneumoniae organisms in the respiratory tract [52, $65,70]$ and decrease the infection level in a herd [71].

Different factors that may influence vaccine efficacy have been described by Maes et al. [60]. The most important factors include non-compliance with the basic principles of good vaccination practices, stress at vaccination, infections with other pathogens at the moment of vaccination, important co-infections involved in porcine respiratory disease complex, diversity of $M$. hyopneumoniae strains, and maternal immunity. A recent study [72] also hinted at a role of pre-vaccination gut microbiota composition in influencing $M$. hyopneumoniae vaccine responses, although bacterial diversity indexes alone were not predictive for antibody responses among individual pigs.

Drawbacks of the current vaccines are that the protection against clinical signs and lesions typically caused by $M$. hyopneumoniae is often incomplete and vaccination does not prevent colonization. Transmission models under experimental [70] and field conditions $[45,73]$ also showed that vaccination conferred only a limited and non-significant reduction of the transmission rate of $M$. hyopneumoniae. New vaccines and/or administration routes are therefore needed. A recent pilot study could not demonstrate transmission 
of $M$. hyopneumoniae between seeder and contact animals in case both had been vaccinated multiple times against $M$. hyopneumoniae [74], suggesting that also the effect of vaccination frequency should be further explored.

\section{Experimental vaccines}

Research on the development of novel vaccines that may offer better protection against $M$. hyopneumoniae infections is ongoing. An overview of the peerreviewed studies (since 1995) that have investigated different experimental vaccines in mice is shown in Table 1 (vector vaccines), Table 2 (subunit vaccines) and Table 3 (DNA vaccines), while studies that were conducted in pigs are shown in Table 4 (vector vaccines), Table 5 (subunit, membrane proteins, culture supernate vaccines) and Table 6 (bacterin vaccines). Peer-reviewed studies about nucleic acid-based vaccines against $M$. hyopneumoniae in pigs were not found. No publications in peer-reviewed scientific journals have been found about experimental vaccines based on attenuated strains.

\subsection{Experimental vaccines studied in mice}

The studies in mice focused on the construction and development of the vaccines and the evaluation of the immune responses. As $M$. hyopneumoniae is only causing disease in pigs, the efficacy of the vaccines was not tested in mice. All studies assessed the humoral responses in serum, many also included cell-mediated immunity (CMI), whereas the humoral response in the BAL fluid was less frequently examined.

In terms of antigen selection, most studies included outer membrane proteins that are immunogenic and/ or considered important for adhesion such as P97, P46, P71 and P95. However, also other antigens were tested such as NrdF, P36, HSP70, P42, P37 and MnuA. NrdF is an essential enzyme for metabolic processes. It catalyzes the conversion of ribonucleoside diphosphates to deoxyribonucleoside diphosphates, an essential step in DNA replication [75]. P36 or L-lactate dehydrogenase is an early immunogenic protein [79]. HSP70 is a $70 \mathrm{kDA}$ heat shock protein that has been used successfully as a vaccine antigen for other pathogens such as Salmonella Typhi in mice and Mycobacterium avium subsp. paratuberculosis in cattle [85]. P42 is also a heat shock protein and is a

Table 1 Experimental vector vaccines against Mycoplasma hyopneumoniae tested in mice.

\begin{tabular}{|c|c|c|c|c|c|c|c|c|}
\hline \multirow[t]{2}{*}{ Antigen } & \multirow[t]{2}{*}{ Vector } & \multirow[t]{2}{*}{ Route } & \multirow{2}{*}{$\begin{array}{l}\mathrm{Nb} \text { of } \\
\text { vaccinations }\end{array}$} & \multicolumn{2}{|c|}{ Humoral response } & \multirow[t]{2}{*}{ CMI response ${ }^{a}$} & \multirow{2}{*}{$\begin{array}{l}\text { Other/ } \\
\text { comments }\end{array}$} & \multirow[t]{2}{*}{ References } \\
\hline & & & & Serum & $\mathrm{BALF}^{\mathrm{b}}$ & & & \\
\hline $\operatorname{NrdF}(R 2)$ & $\begin{array}{l}\text { Salmonella Typh- } \\
\text { imurium aroA } \\
\text { SL3261 }\end{array}$ & Oral & 3 & No lgG, no lgA & $\lg A$, no $\lg G$ & & & {$[75]$} \\
\hline P97 (R1) & $\begin{array}{l}\text { Salmonella Typh- } \\
\text { imurium aroA } \\
\text { CS332 (pro- and } \\
\text { eukaryotic } \\
\text { plasmid) }\end{array}$ & Oral & 2 & No & No & $\mathrm{IFN}-\gamma$ & & {$[76]$} \\
\hline $\operatorname{NrdF}(R 2)$ & $\begin{array}{l}\text { Salmonella } \\
\text { Typhimurium } \\
\text { aroA CS332(pro- } \\
\text { and eukaryotic } \\
\text { plasmid) }\end{array}$ & oral & 2 & No & No & $\begin{array}{l}\text { IFN-y response } \\
\text { (only with } \\
\text { eukaryotic } \\
\text { vector) }\end{array}$ & & {$[77]$} \\
\hline P97 (R1) & Adenovirus & IM or IN & 2 & $\begin{array}{c}\text { IM / IN: IgG } \\
\text { IM: IgG2a/ } \\
\lg G 1=4 \\
\text { IN: } \lg G 2 \mathrm{a} / \\
\lg \mathrm{G} 1=1\end{array}$ & $\begin{array}{l}\mathrm{IM} / \mathrm{IN}: \lg G, \lg G 1 \\
\lg \mathrm{g} 2 \mathrm{a} \\
\mathrm{IN}: \lg \mathrm{A}\end{array}$ & & $\begin{array}{l}\text { Serum and } \\
\text { BAL inhibited } \\
\text { growth of } M \text {. } \\
\text { hyopneumoniae }\end{array}$ & {$[78]$} \\
\hline P36 & $\begin{array}{l}\text { Actinobacillus } \\
\text { pleuropneumo- } \\
\text { niae SLW36 }\end{array}$ & $\mathrm{IM}$ & 2 & $\lg G$ & & & & {$[79]$} \\
\hline P97C & Adenovirus & $\mathrm{IM}$ & 2 & $\begin{array}{c}\lg G, \lg G 1, \lg G 2 a \\
\lg G 2 b, \lg G 3 \\
\lg G 2 a / \lg G 1 \approx 1\end{array}$ & & & $\begin{array}{l}\text { P97c may act as } \\
\text { immunopoten- } \\
\text { tiator }\end{array}$ & {$[80]$} \\
\hline P97R1, P46 & Bacillus subtilis & IN & 2 & $\lg G$ & $\lg A$ & $|F N-\gamma| \mid-4$, & & {$[81]$} \\
\hline
\end{tabular}

IM, Intramuscular; IN, Intranasal.

${ }^{\text {a }} \mathrm{CMI}$ cell-mediated immune responses were tested by stimulation of splenocytes.

${ }^{\mathrm{b}} \mathrm{BALF}$ bronchoalveolar lavage fluid. 


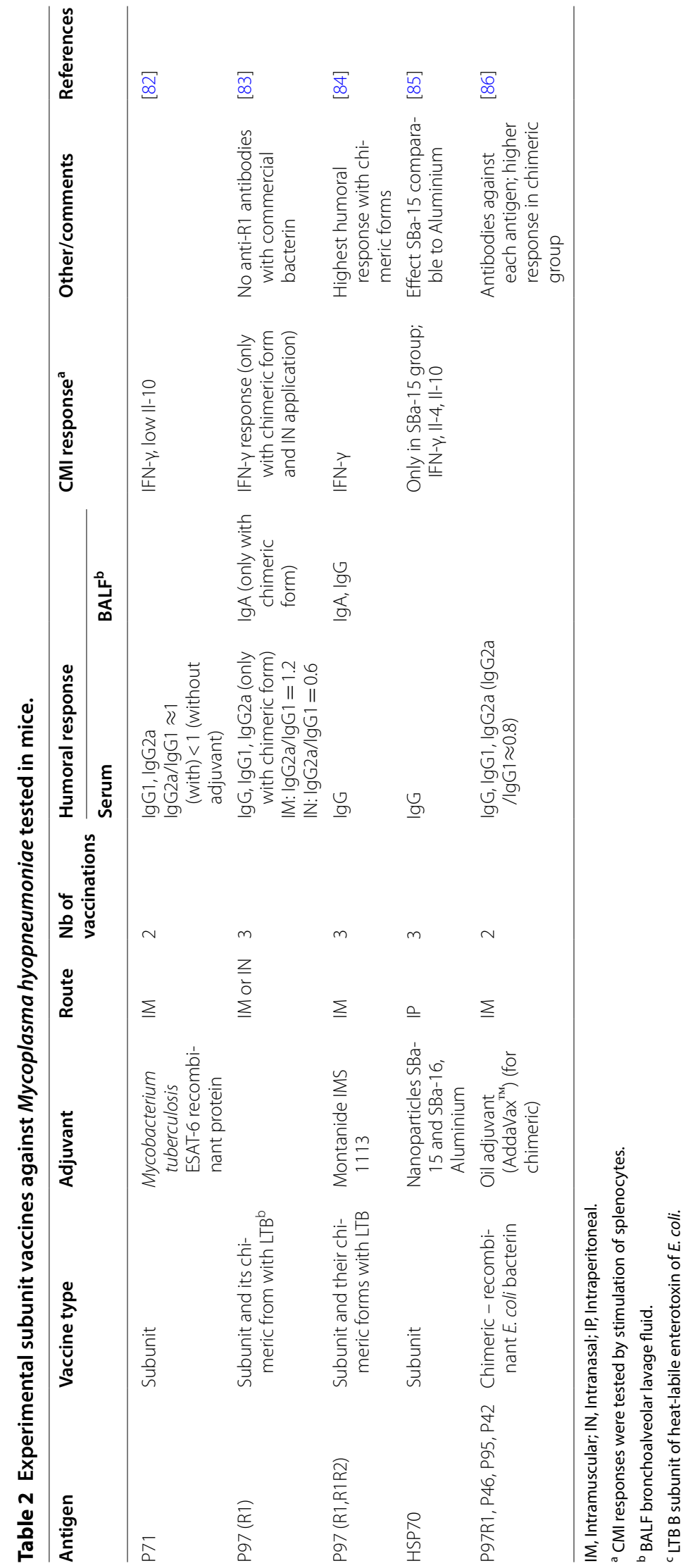


Table 3 Experimental DNA vaccines against Mycoplasma hyopneumoniae tested in mice.

\begin{tabular}{|c|c|c|c|c|c|c|c|c|}
\hline Antigen & Vaccine type & $\begin{array}{l}\text { Vector/ } \\
\text { adjuvant }\end{array}$ & Route & $\begin{array}{l}\text { Nb of } \\
\text { vaccinations }\end{array}$ & $\begin{array}{l}\text { Humoral } \\
\text { response } \\
\text { Serum }\end{array}$ & CMI response $\mathrm{a}^{\mathrm{a}}$ & $\begin{array}{l}\text { Other/ } \\
\text { comments }\end{array}$ & References \\
\hline P42 & DNA & pcDNA3 & IM & 2 & $\begin{array}{l}\lg G, \lg G 1, \lg G 2 a \\
\lg G 2 \mathrm{~b}, \lg G 3 \\
\lg 22 \mathrm{a} / \\
\lg \mathrm{G} 1=1.1)\end{array}$ & $\mid F N-\gamma,\|-2\|-4$, & $\begin{array}{l}\text { Serum inhibited } \\
\text { growth of } M \text {. } \\
\text { hyopneumo- } \\
\text { niae }\end{array}$ & [87] \\
\hline P71 & DNA & $\begin{array}{l}\text { Mycobacterium } \\
\text { tuberculosis } \\
\text { ESAT-6 gene } \\
\text { sequences }\end{array}$ & $\mathrm{IM}$ & 2 & $\begin{array}{l}\operatorname{lgG} 1, \operatorname{lgG} 2 \mathrm{a} \\
\text { (higher } \\
\text { responses and } \\
\text { lgG2a/lgG1 } \\
\text { ratio in group } \\
\text { with adjuvant) }\end{array}$ & $\begin{array}{l}\text { IFN-y (higher in } \\
\text { group with } \\
\text { adjuvant), no } \\
\text { ॥-10 }\end{array}$ & & [88] \\
\hline $\begin{array}{l}\text { P36, P46, NrdF, } \\
\text { and P97or } \\
\text { P97R1 }\end{array}$ & $\begin{array}{l}\text { Subunit (cock- } \\
\text { tail), DNA, } \\
\text { combination }\end{array}$ & $\begin{array}{l}\text { Subunit: } \\
\text { Aluminium } \\
\text { pcDNA3 }\end{array}$ & $\begin{array}{l}\text { Subunit: SC } \\
\text { DNA: IM }\end{array}$ & 1 & $\begin{array}{l}\text { Subunit, com- } \\
\text { bination: IgG } \\
\text { against each } \\
\text { antigen } \\
\text { DNA: IgG only } \\
\text { against P46 }\end{array}$ & $\mathrm{IFN}-\gamma$ & $\begin{array}{l}\text { Commercial } \\
\text { vaccine: no } \\
\text { anti-P97 } \\
\text { antibodies }\end{array}$ & [89] \\
\hline $\begin{array}{l}\text { P37, P42, } \\
\text { P46, P95 }\end{array}$ & $\begin{array}{l}\text { Subunit (cock- } \\
\text { tail) and DNA }\end{array}$ & $\begin{array}{l}\text { Subunit: } \\
\text { Aluminium } \\
\text { pcDNA3 }\end{array}$ & $\mathrm{IM}$ & 2 & & $\begin{array}{l}\text { IFN- } \gamma \text {, lower } \\
\text { TNFa and II-1 }\end{array}$ & $\begin{array}{l}\text { Strongest } \\
\text { response for } \\
\text { P42 and P95 } \\
\text { (subunit) and } \\
\text { for P46 (DNA) }\end{array}$ & [90] \\
\hline $\begin{array}{l}\text { P46, HSP70, } \\
\text { MnuA anti- } \\
\text { gens }\end{array}$ & $\begin{array}{l}\text { Subunit (cock- } \\
\text { tail) and DNA }\end{array}$ & $\begin{array}{l}\text { Subunit: Fre- } \\
\text { und's adjuvant } \\
\text { pcDNA3.1 }\end{array}$ & $\begin{array}{l}\text { Subunits: IP } \\
\text { DNA: IM }\end{array}$ & 3 & $\lg G$ & $\begin{array}{l}\text { IFN- }-\gamma \text {, II-10, no } \\
\|-4\end{array}$ & $\begin{array}{l}\text { Mixed response, } \\
\text { but predomi- } \\
\text { nantly Th1 }\end{array}$ & [91] \\
\hline
\end{tabular}

IM, Intramuscular; SC, Subcutaneous; IP, intraperitoneal.

${ }^{\text {a }} \mathrm{CMI}$ responses were tested by stimulation of splenocytes.

member of the HSP70 family [86]. It is highly expressed under stress conditions, and specific antibodies against P42 were able to block the growth of M. hyopneumoniae. P37 is a lipoprotein that belongs to the ATP-binding cassette (ABC) transporters [90], whereas MnuA is a membrane nuclease and considered a potential virulence factor [91]. The antigens in the vaccines were produced by recombinant DNA technology using $E$. coli as expression system.

Most vector vaccines were based on bacterial vectors namely Salmonella, Actinobacillus and Bacillus, while two studies used adenovirus vectors. The subunit vaccines were based on single antigens or different antigens that were mixed with an adjuvant. In three of the five studies, the antigens were constructed as a chimeric protein. Subunit vaccines were used in combination with adjuvants based on oil, aluminium hydroxide, the B subunit of heat-labile enterotoxin of E. coli (LTB) or Mycobacterium tuberculosis ESAT-6 protein. Vaccination with DNA constructs encoding potential antigens might be promising, as in general, DNA constructs are stable, easy to handle and can be administered via various routes.

Most vaccines in mice were applied two or three times, and were administered via the parenteral route, mainly intramuscularly, although oral (vector vaccines), intranasal and intraperitoneal administration routes were evaluated as well.

The major outcome parameters of the studies in mice were humoral responses in serum and in some studies also in BAL fluid, and CMI responses. Humoral responses in serum were assessed by measuring IgG against the antigens included in the vaccine, some studies also measured isotypes of IgG. In general, IgG1 in mice is indicative of a Th2 response, whereas IgG2a is predominantly produced during a Th1-type response [92]. CMI responses were examined by isolation and subsequent stimulation of splenocytes with the respective antigens. IFN $-\gamma$ production by splenocytes was measured in every study, other cytokines (IL-10, IL-4, TNF- $\alpha$ ) were less frequently assessed.

The immune responses with the orally applied Salmonella vector vaccine were poor, IgA was only found in BAL fluid in one study and IFN- $\gamma$ production in another study (Table 1). The immune responses with the other vector vaccines that were administered intramuscularly or intranasally were more pronounced, but also variable between studies. When used under field conditions, vector vaccines might have the problem that immunity is present in the animals against 


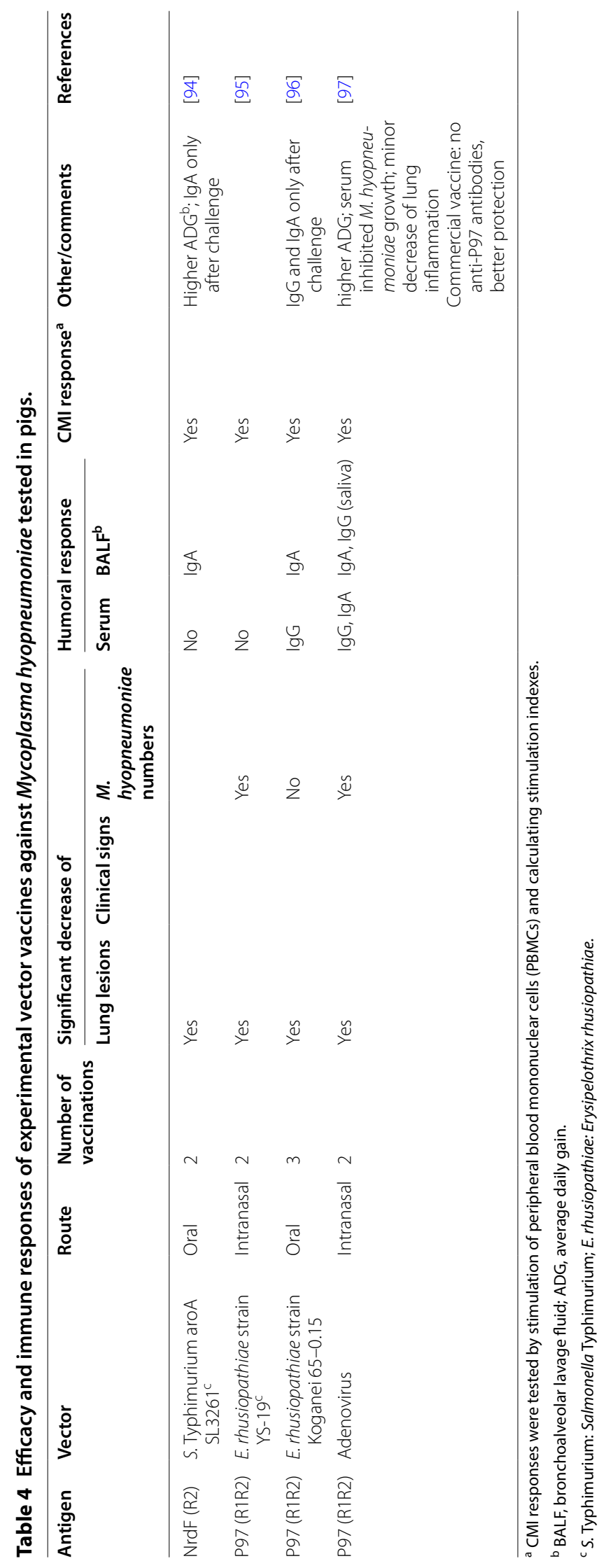




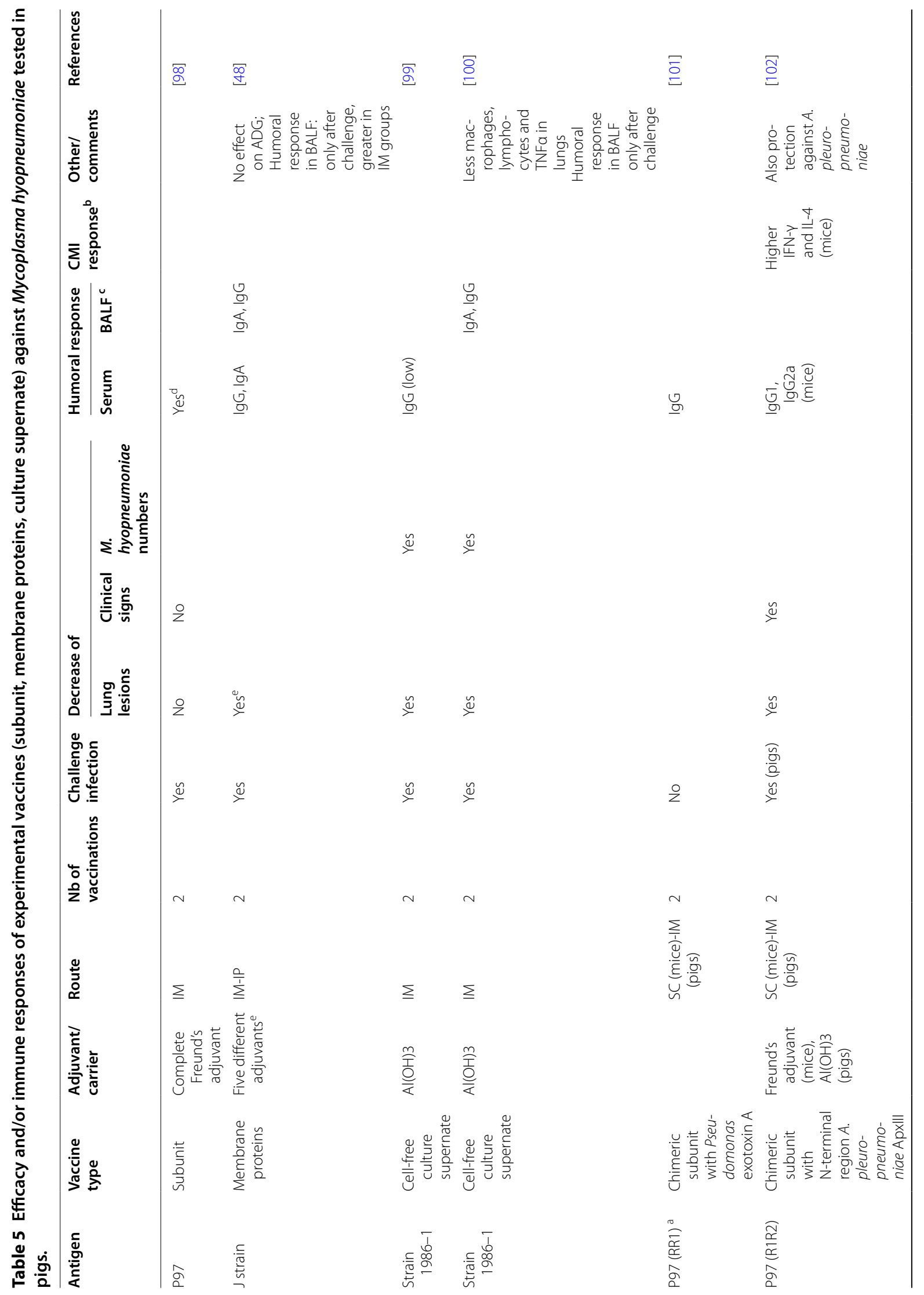




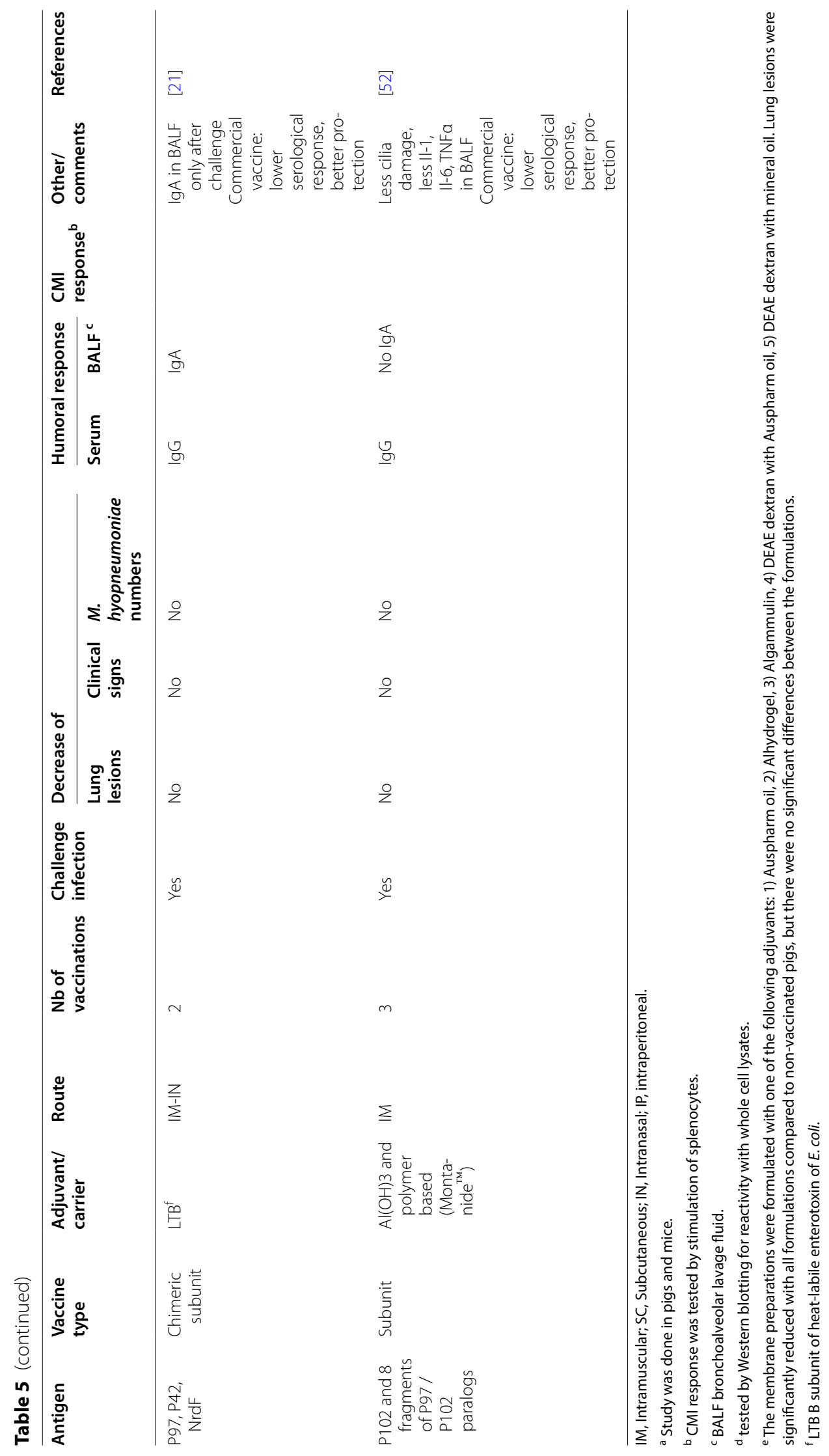




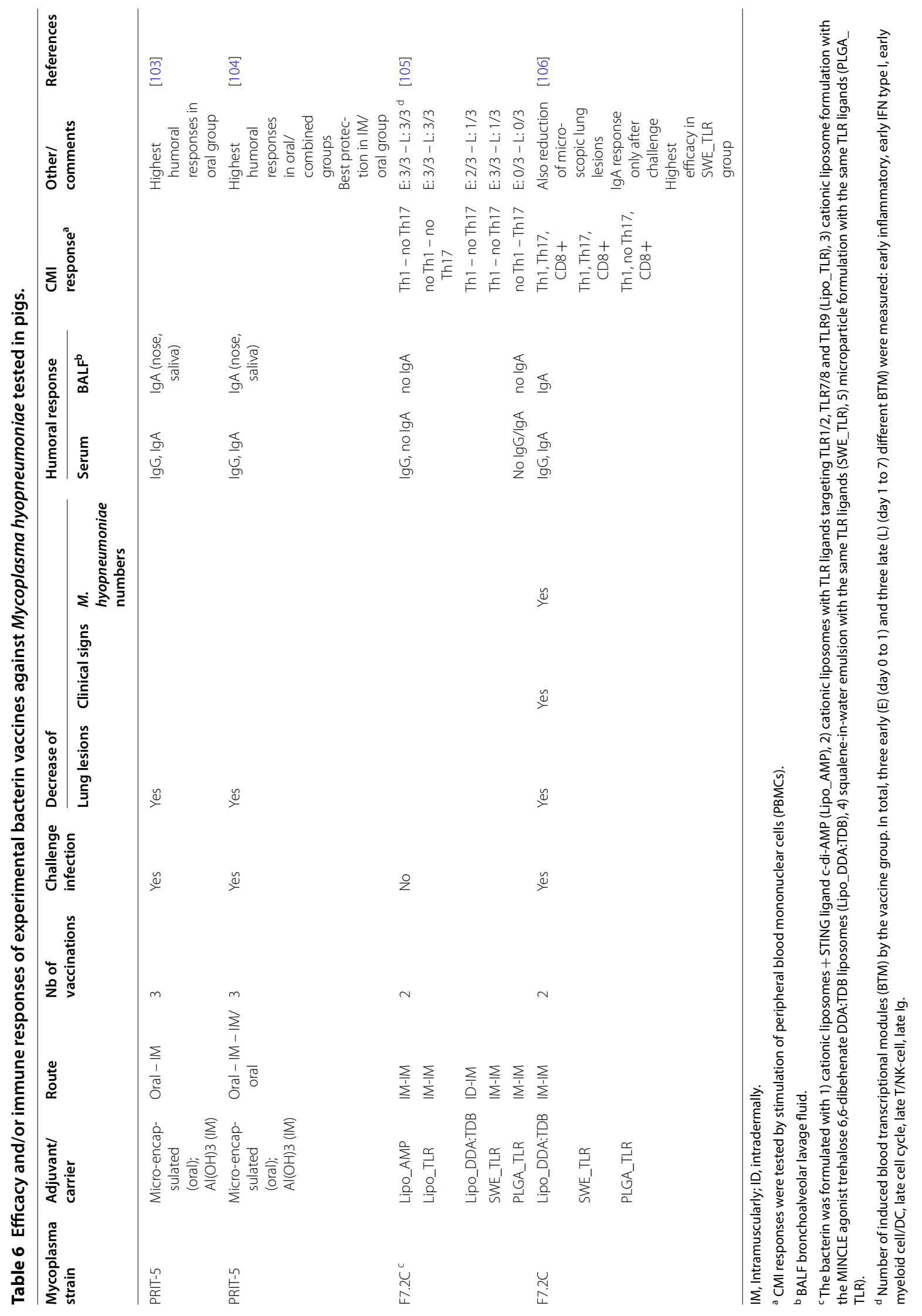


the vector micro-organism e.g. Salmonella, leading to lower expression of and immunity against the carried antigen.

The immune responses following administration of subunit vaccines (Table 2) were more consistently measured compared to those of the vector vaccines. Mostly, mixed Th1/Th2 responses were obtained. Immune responses were generally more pronounced when different antigens were presented in a chimeric form [83, 84, 86]. Possibly, in these studies, the epitopes were better accessible by the immune system in the chimeric proteins. Immunization by the intramuscular route appeared to favor a Th1-type response (higher IgG2/IgG1 ratio), while the intranasal route induced a mixed response [78, 83]. Adding Mycobacterium tuberculosis ESAT-6 protein or the gene sequences as adjuvant also shifted the immune response towards a Th1-type response [82].

Vaccination with the DNA constructs elicited mixed responses (Table 3), with predominance for Th1-type responses $[87,91]$. IgA in BAL fluid was not tested. Th1type responses stimulate B-cells to produce strongly opsonizing antibodies, such as IgG2a and IgG2b in mice, enhancing the phagocytosis by alveolar macrophages. In mice, IFN- $\gamma$, produced by Th1-type cells, induces nitric oxide release from monocytes/macrophages. In case genes coding for multiple antigens were included [89-91], the responses were variable between the antigens, and could also be different when compared to the response obtained by the respective single subunit vaccines.

Overall, some studies showed promising immune responses in mice. However, many phenotypic as well as functional differences in immune cell populations exist between the porcine and the murine immune system [93]. Therefore, studies in mice should be considered as preliminary and need to be validated in pigs.

\subsection{Experimental vaccines studied in pigs}

The experimental vaccine studies in pigs are summarized in Tables 4, 5 and 6. Most of the studies in pigs used an experimental challenge infection model, allowing to assess the efficacy of the vaccines. CMI responses in pigs were tested by stimulation of PBMCs and subsequently measuring the stimulation index (vector vaccines) or specific cytokine responses (bacterin vaccines). No CMI responses were measured in the studies with the subunit vaccines.

The antigen selection for the vector and subunit vaccines mostly included the P97, alone or in combination with other antigens e.g. NrdF, P42 or P102. One study used membrane proteins [48] and two studies used cell-free culture supernatant of M. hyopneumoniae [99, 100]. The bacterin vaccines were based on the strains
PRIT-5 [103, 104] and F7.2C [105, 106]. Subunit and bacterin vaccines were mostly used in combination with an adjuvant such as aluminium hydroxide, Freund's adjuvant (both complete or incomplete), bacterial toxin subunits (LTB), oil or polymer-based adjuvants, macrophage-inducible C-type lectin (MINCLE) agonist, the stimulator of interferon genes (STING) ligand and a combination of different TLR ligands. Vectors used were Salmonella Typhimurium, Erysipelothrix rhusiopathiae and adenovirus. Vector vaccines were administered orally or intranasally, while most subunit and bacterin vaccines were administered parenterally. In two studies, the bacterin was provided orally in microspheres [103, 104]. All experimental vaccines in pigs were applied two or three times.

In terms of efficacy, 11 out of 14 studies showed a significant reduction of the lung lesions caused by $M$. hyopneumoniae upon challenge infection. Two out of five studies showed a reduction of clinical signs (coughing), and five out of eight a reduction of the M. hyopneumoniae load in the BAL fluid. Three studies [21, 52, 97] included a commercial bacterin as control. Their efficacy was each time better than for the experimental vaccines, although the immune responses against the epitopes of the experimental vaccines were lower or absent upon vaccination with the commercial vaccines. This might be due to the fact that some proteins of the bacterins might not be expressed or only expressed in negligible amounts under culture conditions [107], or to the formulation or the adjuvant. Proteomic analysis by Pendarvis et al. [108] showed that only 483 of 691 (70\%) proteins in M. hyopneumoniae 232 strain were expressed under in vitro culture conditions. This might be one of the reasons of the incomplete protection induced by commercial vaccines. Nonetheless, the efficacy of the experimental vaccines was even lower, suggesting that immunity induced by the antigens selected for preparing these vaccines is not sufficient for improved protection, although it is well known that these antigens like P97 have important roles in the pathogenesis of $M$. hyopneumoniae infections.

All studies could demonstrate specific IgG responses in the serum, except for two vector vaccines [94, 95]. In all studies that had measured mucosal IgA responses in the BAL fluid, IgA could only be detected after challenge infection, but not after vaccination prior to challenge (four studies used intramuscular, two studies oral administration). In three studies [97, 103, 104], IgA was detected in the saliva and/or nose after vaccination and prior to challenge infection. In these studies, pigs were vaccinated intranasally, orally or intramuscularly. In the pigs vaccinated intramuscularly, IgA levels in the saliva and especially in the nose were low [103, 104]. 
In terms of CMI responses, all studies with the vector vaccines could demonstrate significant responses upon specific stimulation of PBMCs. None of the studies with subunit vaccines (Table 5) describe assessment of CMI responses. For the bacterin vaccines, CMI responses were only assessed in the studies of Matthijs et al. [105, 106]. The study of Matthijs et al. [105] did not apply challenge infection, but made a detailed assessment of the immune responses of five different bacterin formulations. They were all based on a more recently isolated field strain of $M$. hyopneumoniae compared to the type strain J, in combination with different novel adjuvants. These included different Toll-like receptor ligands (targeting TLR1/2, TLR7/8, TLR9), the MINCLE agonist trehalose 6,6-dibehenate (TDB), and STING ligand cyclic diadenylate monophosphate (c-di-AMP). They were used in combination with different carriers namely liposomes, polylactic-co-glycolic acid (PLGA) microparticles or squalene-in-water emulsion (SWE) (see Table 6). The responses were variable depending on the group. Lipo_DDA:TDB, Lipo_AMP and SWE_TLR significantly induced Th1 cytokine-secreting T cells. Only PLGA_TLR appeared to induce Th17 cells, but was unable to induce serum antibodies.

The study of Matthijs et al. [106] also applied a systems vaccinology approach developed for humans and adapted the approach for use in pigs. The transcriptomic analyses demonstrated that the induction of inflammatory and myeloid cell blood transcriptional modules (BTM) in the first $24 \mathrm{~h}$ after vaccination correlated well with serum antibodies, while negative correlations with the same modules were found seven days post vaccination. Furthermore, many cell cycle and T cell BTM upregulated at day seven, correlated positively with adaptive immune responses. When comparing the delivery of the identical TLR ligands with the three formulations, SWE_TLR was shown to be more potent in the induction of an early innate immune response, while the liposomal formulation more strongly promoted late cell cycle and $\mathrm{T}$ cell BTM. For the PLGA formulation, there were signs of a delayed and weak perturbation of these BTM. The study of Matthijs et al. [105] demonstrated the utility of transcriptome-based systems immunology analyses in identifying early immune signatures in the blood and in unraveling the mechanistic events leading to the stimulation of adaptive immune responses after vaccine injection in pigs.

In a subsequent study, Matthijs et al. [106] assessed the efficacy of three bacterin formulations that were able to induce a Th1 or Th17 response in the previous study, namely a cationic liposome formulation with the Mincle receptor ligand trehalose 6,6-dibehenate (Lipo_ DDA:TDB), a squalene-in-water emulsion with Toll-like receptor (TLR) ligands targeting TLR1/2, TLR7/8 and TLR9 (SWE_TLR), and a poly(lactic-co-glycolic acid) microparticle formulation with the same TLR ligands (PLGA_TLR). All three formulations showed promising results, but the highest CMI responses were obtained in the SWE_TLR group. This experimental vaccine also showed the best efficacy in terms of reducing clinical signs, lung lesions and bacterial load in the lung.

Overall, the research with the different experimental vaccines in pigs suggests that the construction, the type of antigens, the adjuvant and/or carrier, and the route and frequency of immunization could induce variable immune responses and efficacy. Based on the available studies, it is not possible to unravel the effect of one of these characteristics e.g. antigen, adjuvant and administration route, as the studies were not designed for this purpose and differ each time in more than one characteristic. In addition, the studies listed in Tables 1 and 2 also point to a large variation in individual animal responses, even if the same vaccine is used under the same conditions.

\section{Avenues for further research}

As far as this was investigated, the experimental vaccines that have been tested in pigs (Tables $4,5,6$ ) do not provide superior protection compared to the commercially available bacterin vaccines. Therefore, further research on the development of new experimental vaccines and validation of the efficacy of promising vaccines in pigs is needed.

From an immunological point of view, a major challenge is to induce a protective immunity at the mucosal surface of primary adherence and multiplication of $M$. hyopneumoniae, namely the ciliated epithelium of the trachea, bronchi and bronchioli. From a practical viewpoint, also aspects such as cost of the vaccine, ease of production, transport and administration, differentiation of infected from vaccinated animals (DIVA), and possible combination with other vaccines are important.

\subsection{Administration route}

Administration of the antigens intranasally or via aerosols might be the most appropriate routes to accomplish mucosal protection. The number of experimental vaccines that have evaluated this route of immunization is still very limited. This is mainly due to important difficulties that are encountered by using the mucosal route such as: (1) the antigen should be present at and below the mucosal barrier in sufficient amounts allowing sufficient capturing by antigen presenting cells, (2) mucosal tolerance mechanisms should be overcome, (3) protective immune mechanisms should be activated and, (4) minimal/or no influence on mucosal functionality should 
occur. Mucosal adjuvants e.g. microbe-derived substances, including TLR ligands, could be crucial in reaching these goals $[109,110]$. Heterologous prime-boost regimes e.g. intramuscular followed by mucosal administration or vice versa, allowing a broader or more variable triggering of the immune system, might also be considered. Vaccination via aerosols is probably technically possible, as nebulization of lung homogenate positive for $M$. hyopneumoniae to gilts under field conditions, resulted in infection of the animals with this pathogen [111]. Also, Feng et al. [62] showed that the attenuated vaccine used in China could be administrated as an aerosol.

Providing the antigen orally might also induce mucosal immunity in the respiratory tract via the common mucosal immune system [112]. In the studies of Lin et al. [103, 104], microencapsulated inactivated whole-cell $M$. hyopneumoniae vaccine was administered orally to pigs via a tube into the esophagus on three occasions. IgA was detected in nasal secretions and saliva, but IgA was not measured in BAL fluid. However, lung lesions following challenge infection were significantly reduced in vaccinated pigs, pointing to protective immunity in these animals. Placing a tube in the esophagus is labor intensive, time consuming and not animal welfare friendly. The stability of the antigen during the mouth-stomach-intestine passage might also be an issue. Therefore, further research should focus on whether $M$. hyopneumoniae vaccines mixed in the diet and consumed by the pigs can also provide protection. Such a method might require a higher antigen dose and also the stability of the antigen in the feed might be an issue. However, it would be animal welfare friendly and require much less time and labor than administration of the vaccine via a tube to each individual animal.

Most experimental vaccines were applied via the parenteral route, mostly intramuscularly. The studies using parenteral administration however could not demonstrate measurable IgA responses in the BAL fluid prior to challenge, and therefore, this route is less suitable for inducing mucosal humoral responses. However, higher M. hyopneumoniae-specific IgA levels were observed in respiratory tract washings of parenterally vaccinated pigs compared to non-vaccinated pigs after challenge infection, indicating an anamnestic immune response. This suggests that priming of the mucosal immune system is possible after parenteral vaccine administration. Intradermal vaccination directly targets epidermal Langerhans cells and dermal dendritic cells, which are essential for efficient $\mathrm{T}$ and $\mathrm{B}$ cell priming. In this sense, intradermal vaccination against $M$. hyopneumoniae can be an asset, as more of these specialized APCs are present in the skin compared to muscle tissue [113]. In addition, no needles are used as the vaccine is administered intradermal via pressure, which may reduce the risk for iatrogenic infections.

\subsection{Antigen}

Bacterial genes and antigens involved in survival of the bacterium in the host and/or that render the bacterium harmful to the host could be included in vaccines or could be targets for attenuation to develop attenuated vaccines. Many experimental vaccine studies have included P97 and other proteins that are important for adherence or metabolism. However, subunit vaccines based on the most important adhesion namely P97, did not provide sufficient protection. The adhesion process is complex and involves many different adhesins, therefore, including one or only a few antigens might be insufficient. This might also explain why bacterins, which include a broad array of antigens, perform better in terms of efficacy than subunit vaccines. Further research on subunit vaccines should therefore not focus on one or a few antigens, but include different and carefully selected antigens.

\subsection{Adjuvant and carrier}

Adjuvants are incorporated into vaccines to increase and direct the immunogenic responses to antigens. Many adjuvants activate the innate immune system through pattern-recognition receptors (PRRs) present in immune cells. Receptor-ligand interactions lead to expression of genes that encode cytokines, chemokines, and costimulatory molecules responsible for priming, expansion, and polarization of immune responses [114]. Adjuvants can also induce adaptive immune responses either by enhancing $\mathrm{T}$ cell responses, by stimulating humoral immunity or both. As Th1 and Th17 responses are considered important for protection against M. hyopneumoniae infection, adjuvants that stimulate this arm of the immune system should preferably be selected [105]. Commonly used adjuvants and their modes of action along with strengths and weaknesses have been reviewed by Bastola et al. [114].

Adjuvants not only increase the immunogenic responses, but can also lead to adverse reactions such as inflammation at the injection site, granuloma and sterile abscess formation, malaise, fever and other systemic reactions. Apart from the study of Matthijs et al. [105], information about safety of adjuvants in experimental M. hyopneumoniae vaccines is very scarce. Research on adjuvant development should therefore not only identify more inflammatory adjuvants, but also try to separate the potency of adjuvants from the adverse effects they can induce. 


\subsection{Attenuated vaccines}

Attenuated vaccines have great potential to better stimulate a mucosal immune response at the respiratory tract compared to parenterally administered vaccines. However, apart from the two current commercially available attenuated $M$. hyopneumoniae vaccines, very few studies have focused on developing experimental attenuated $M$. hyopneumoniae vaccines. This might be due to the difficult isolation and cultivation characteristics of M. hyopneumoniae. In addition, reversion of virulence is always a concern in case of attenuated vaccines. One study [115] tested whether a low virulent $M$. hyopneumoniae strain could be used as a potential vaccine. However, infection with this strain did not protect piglets against infection with a highly virulent $M$. hyopneumoniae isolate 1 month later, suggesting that low virulent strains might not be suitable as such to be used as vaccines. Current technology allows however to selectively delete specific genes important for replication or virulence in pathogenic organisms, which might be useful for the development of attenuated vaccines against $M$. hyopneumoniae. At this stage however, these genes are not yet fully elucidated, and therefore, further research is needed to investigate genes of M. hyopneumoniae involved in pathogenesis and virulence.

\section{Conclusions}

The very complex interaction of $M$. hyopneumoniae with the respiratory tract and the immune system and the fact that naturally elicited immune responses upon infection are not able to rapidly clear the pathogen from the animal, make the search for protective immune responses and efficacious novel vaccines challenging. Different experimental vaccines against $M$. hyopneumoniae have been developed and tested in mice and pigs. Most of them were based on the P97 adhesin or other factors considered important in the pathogenesis, or were bacterins combined with novel adjuvants. As cell-mediated and likely also mucosal humoral responses are important for protection, new vaccines should aim to target these arms of the immune response. Very few research has been directed towards the development of attenuated vaccines, although such vaccines may have great potential.

\section{Abbreviations}

ABC: ATP-binding cassette; APC: Antigen presenting cell; BAL: Bronchoalveolar lavage; BTM: Blood transcriptional modules; c-di-AMP: Cyclic di-adenylate monophosphate; CMI: Cell-mediated immunity; DC: Dendritic cell; DDA:TDB: Dimethyl dioctadecylammonium:trehalose 6,6-dibehenate; DIVA: Differentiation of infected from vaccinated animals; HSP: Heat shock protein; ICE: Integrative and conjugative elements; IFN: Interferon; Ig: Immunoglobulin; IL: Interleukin; IN: Intranasal; LAMP: Lipid associated membrane proteins; LTB: Heat-labile enterotoxin of E. coli; M. hyopneumoniae: Mycoplasma hyopneumoniae; MET: Macrophage extracellular trap; MIB: Mycoplasma lg binding protein; MINCLE: Macrophage-inducible C-type lectin; MIP: Mycoplasma lg protease;
}

NET: Neutrophil extracellular trap; NK: Natural killer; NrdF: Ribonucleosidediphosphate reductase; PBMC: Peripheral blood mononuclear cell; PGLA: Poly(lactic-co-glycolic acid); STING: Stimulator of interferon genes; SWE: Squalene-in-water; Th: T helper; TLR: Toll-like receptor; TNF: Tumor necrosis factor.

\section{Authors' contributions}

DM wrote the paper. All co-authors have critically revised the manuscript, FB, PK and FH with emphasis on the bacteriological aspects, BV and AS with emphasis on the immune responses and vaccination. The authors have collaborated intensively on the topic during the H2020 Project SAPHIR (Project No. 633184) (2015-2019). All authors have read and approved the final manuscript.

\section{Declarations}

\section{Competing interests}

The authors declare that they have no competing interests.

\section{Author details}

${ }^{1}$ Faculty of Veterinary Medicine, Ghent University, Merelbeke, Belgium. ${ }^{2}$ Institute of Veterinary Bacteriology, Vetsuisse Faculty, University of Bern, Bern, Switzerland. ${ }^{3}$ Institute of Virology and Immunology, Sensemattstrasse 293, Mittelhäusern, Switzerland. ${ }^{4}$ Department of Infectious Diseases and Pathobiology, Vetsuisse Faculty, University of Bern, Bern, Switzerland.

Received: 17 February 2021 Accepted: 23 April 2021

Published online: 08 May 2021

\section{References}

1. Pieters M, Maes D (2019) Mycoplasmosis. In: Zimmermann JJ, Karriker LA, Ramirez A, Schwartz KJ, Stevenson GW, Zhang J Diseases of swine (11 ed). Hoboken, NJ, Wiley. pp: 863-883

2. Marois C, Segalés J, Holtkamp D, Chae C, Deblanc C, Opriessnig T, Fablet C (2020) Interactions of Mycoplasma hyopneumoniae with other pathogens and economic impact. In: Book Mycoplasmas in Swine. Chapter 7. Editors: Dominiek Maes, Marina Sibila, Maria Pieters. ISBN 978-94-6379796-2, Acco Publishers, Leuven Belgium, 127-145

3. Blanchard B, Vena MM, Cavalier A, Le Lannic J, Gouranton J, Kobisch $M$ (1992) Electron microscopic observation of the respiratory tract of SPF piglets inoculated with Mycoplasma hyopneumoniae. Vet Microbiol 30:329-341

4. Summerfield A (2020) Immune responses against porcine Mycoplasma infections. In: Book Mycoplasmas in Swine. Chapter 6. Editors: Dominiek Maes, Marina Sibila, Maria Pieters. ISBN 978-94-6379-796-2, Acco Publishers, Leuven Belgium, pp. 110-125

5. Marco E, Yeske P, Pieters M (2020) General control measures against Mycoplasma hyopneumoniae infections. In: Book Mycoplasmas in Swine. Chapter 9. Editors: Dominiek Maes, Marina Sibila, Maria Pieters. ISBN 978-94-6379-796-2, Acco Publishers, Leuven Belgium. pp. 163-180

6. Thacker E, Thacker B, Wolff T (2004) Efficacy of a chlortetracycline feed additive in reducing pneumonia and clinical signs induced by experimental Mycoplasma hyopneumoniae challenge. J Swine Health Prod $14: 140-144$

7. Collignon PJ, McEwen SA (2019) One health-its importance in helping to better control antimicrobial resistance. Trop Med Infect Dis 4:22

8. Jarocki V, Djordjevic S (2020) Diversity of Mycoplasma hyopneumoniae strains. In: Book Mycoplasmas in Swine. Chapter 2. Editors: Maes D, Sibila M, Pieters M. ISBN 978-94-6379-796-2, Acco Publishers, Leuven Belgium. pp. 47-71

9. Minion FC, Lefkowitz E, Madsen M, Cleary B, Swartzell S, Mahairas G (2004) The genome sequence of Mycoplasma hyopneumoniae strain 232, the agent of swine mycoplasmosis. J Bacteriol 186:7123-7133

10. Vasconcelos A, Ferreira H, Bizarro C, Bonatto S, Carvalho M, Pinto P, Almeida DF, Almeida LGP, Almeida R, Alves-Filho L, Assunção EN, Azevedo VAC, Bogo MR, Brigido MM, Brocchi M, Burity HE, Camargo AA, Camargo SS, Carepo MS, Carraro DM, de Mattos Cascardo JC, Castro LA, Cavalcanti G, Chemale G, Collevatti RG, Cunha CW, Dallagiovanna B, 
Dambrós BP, Dellagostin OA et al (2005) Swine and poultry pathogens: the complete genome sequences of two strains of Mycoplasma hyopneumoniae and a strain of Mycoplasma synoviae. J Bacteriol 187:5568-5577

11. Leal Zimmer F, Paes J, Zaha A, Ferreira H (2020) Pathogenicity \& virulence of Mycoplasma hyopneumoniae. Virulence 11:1600-1622

12. Felde $\mathrm{O}$, Kreizinger Z, Sulyok KM, Hrivnák V, Kiss K, Jerzsele A, Biksi I, Gyuranecz M (2018) Antibiotic susceptibility testing of Mycoplasma hyopneumoniae field isolates from Central Europe for fifteen antibiotics by microbroth dilution method. PLoS One 13:e0209030

13. Fritsch TE, Siqueira FM, Schrank IS (2015) Intrinsic terminators in Mycoplasma hyopneumoniae transcription. BMC Genomics 16:273-284

14. Rycroft A (2020) Overview of the general characteristics and classification of porcine Mycoplasma species. In: Book Mycoplasmas in Swine. Chapter 1. Editors: Maes D, Sibila M, Pieters M. ISBN 978-94-6379-796-2, Acco Publishers, Leuven Belgium. pp. 25-46

15. Simionatto S, Marchioro SB, Galli V, Luerce T, Hartwig D, Moreira A, Dellagostin O (2009) Efficient site-directed mutagenesis using an overlap extension-PCR method for expressing Mycoplasma hyopneumoniae genes in Escherichia coli. J Microbiol Methods 79:101-105

16. Debey MC, Ross RF (1994) Ciliostasis and loss of cilia induced by Mycoplasma hyopneumoniae in porcine tracheal organ cultures. Infect Immun 62:5312-5318

17. Maes D, Sibila M, Kuhnert P, Segalés J, Haesebrouck F, Pieters M (2018) Update on Mycoplasma hyopneumoniae infections in pigs: knowledge gaps for improved disease control. Transbound Emerg Dis 65:110-124

18. Kuhnert P, Jores J (2020) Mycoplasma hyopneumoniae pathogenicity: the know and the unknown. In: Book Mycoplasmas in Swine. Chapter 3. Editors: Maes D, Sibila M, Pieters M. ISBN 978-94-6379-796-2, Acco Publishers, Leuven Belgium. pp. 71-84

19. Raymond BB, Jenkins C, Seymour LM, Tacchi J, Widjaja M, Jarocki V Deutscher A, Turnbull L, Whitchurch C, Padula M, Djordjevic S (2015) Proteolytic processing of the cilium adhesion MHJ_0194 (P123J) in Mycoplasma hyopneumoniae generates a functionally diverse array of cleavage fragments that bind multiple host molecules. Cell Microbiol 17:425-444

20. Jenkins C, Wilton JL, Minion FC, Falconer L, Walker MJ, Djordjevic SP (2006) Two domains within the Mycoplasma hyopneumoniae cilium adhesin bind heparin. Infect Immun 74:481-487

21. Marchioro S, Del Pozo SR, Michiels A, Haesebrouck F, Conceição F, Dellagostin O, Maes D (2014) Immune responses of a chimeric protein vaccine containing Mycoplasma hyopneumoniae antigens and LTB against experimental M. hyopneumoniae infection in pigs. Vaccine 32:4689-4694

22. Kucharewicz I, Kowal K, Buczko W, Bodzenta-Lukaszyk A (2003) The plasmin systemin airway remodelling. Thromb Res 112:1-7

23. Raymond B, Madhkoor R, Schleicher I, Uphoff C, Turnbull L, Whitchurch C, Rohde M, Padula M, Djordjevic S (2018) Extracellular actin is a receptor for Mycoplasma hyopneumoniae. Front Cell Infect Microbiol 8:54

24. Paes JA, Machado LDPN, dos Anjos Leal FM, de Moraes SN, Moura H, Barr JR, Ferreira HB (2018) Comparative proteomics of two Mycoplasma hyopneumoniae strains and Mycoplasma flocculare identified potential porcine enzootic pneumonia determinants. Virulence 9:1230-1246

25. Ferrarini MG, Mucha SG, Parrot D, Meiffrein G, Ruggiero Bachega JF, Comte G, Zaha A, Sagot MF (2018) Hydrogen peroxide production and myo-inositol metabolism as important traits for virulence of $\mathrm{Myco-}$ plasma hyopneumoniae. Mol Microbiol 108:683-696

26. Zuo LL, Wu YM, You XX (2009) Mycoplasma lipoproteins and Toll-like receptors. J Zhejiang Univ Sci B 10:67-76

27. Bai F, Ni B, Liu M, Feng Z, Xiong Q, Shao G (2015) Mycoplasma hyopneumoniae-derived lipid-associated membrane proteins induce inflammation and apoptosis in porcine peripheral blood mononuclear cells in vitro. Vet Microbiol 175:58-67

28. Liu M, Du G, Liu B, Hu Y, Liu J, Jia Y, Minion FC, Shao G, Zhao R (2017) Cholesterol exacerbates Mycoplasma hyopneumoniae-induced apoptosis via stimulating proliferation and adhesion to porcine alveolar macrophages. Vet Microbiol 211:112-118

29. Mitiku F, Hartley CA, Sansom FM, Coombe JE, Mansell PD, Beggs DS, Browning GF (2018) The major membrane nuclease MnuA degrades neutrophil extracellular traps induced by Mycoplasma bovis. Vet Microbiol 218:13-19
30. Henthorn CR, Minion CF, Sahin O (2018) Utilization of macrophage extracellular trap nucleotides by Mycoplasma hyopneumoniae. Microbiology 164:1394-1404

31. Li P, Zhang Y, Li X, Zhou W, Li X, Jiang F, Wu W (2019) Mycoplasma hyopneumoniae Mhp597 is a cytotoxicity, inflammation and immunosuppression associated nuclease. Vet Microbiol 235:53-62

32. Raymond B, Turnbull L, Jenkins C, Madhkoor R, Schleicher I, Uphoff C, Whitchurch C, Rohde M, Djordjevic S (2018) Mycoplasma hyopneumoniae resides intracellularly within porcine epithelial cells. Sci Rep 8:17697

33. Grover RK, Zhu X, Nieusma T, Jones T, Boreo I, MacLeod A, Mark A, Niessen S, Kom H, Kong L, Assad-Garcia N, Kwon K, Chesi M, Smider V, Salomon D, Jelinek D, Kyle R, Pyles R, Glass J, Ward A, Wilson I, Lerner R (2014) A structurally distinct human mycoplasma protein that generically blocks antigen-antibody union. Science 343:656-661

34. Arfi Y, Minder L, Di Primo C, Le-Roy A, Ebel C, Coquet L, Claverol S, Vashee S, Jores J, Blanchard A, Sirand-Pugnet P (2016) MIB-MIP is a mycoplasma system that captures and cleaves immunoglobulin G. Proc Natl Acad Sci U S A 113:5406-5011

35. Pinto PM, de Carvalho MO, Alves-Junior L, Brocchi M, Schrank IS (2007) Molecular analysis of an integrative conjugative element, ICEH, present in the chromosome of different strains of Mycoplasma hyopneumoniae. Genet Mol Biol 30:256-263

36. Liu W, Xiao S, Li M, Guo S, Li S, Luo R, Feng Z, Li B, Zhou Z, Shao G, Chen H, Fang L (2013) Comparative genomic analyses of Mycoplasma hyopneumoniae pathogenic 168 Strain and its high-passaged attenuated strain. BMC Genomics 14:80

37. Browning GF, Marenda MS, Noormohammadi AH, Markham PF (2011) The central role of lipoproteins in the pathogenesis of mycoplasmoses. Vet Microbiol 153:44-50

38. Dobbs NA, Odeh AN, Sun X, Simecka JW (2009) The multifaceted role of T cell-mediated immunity in pathogenesis and resistance to Mycoplasma respiratory disease. Curr Trends Immunol 10:1-19

39. Lorenzo H, Quesada O, Assuncao P, Castro A, Rodriguez F (2006) Cytokine expression in porcine lungs experimentally infected with Mycoplasma hyopneumoniae. Vet Immunol Immunopathol 109:199-207

40. Muneta $Y$, Uenishi $H$, Kikuma R, Yoshihara K, Shimoji Y, Yamamoto R, Hamashima N, Yokomizo Y, Mori Y (2003) Porcine TLR2 and TLR6: identification and their involvement in Mycoplasma hyopneumoniae infection. J Interferon Cytokine Res 23:583-590

41. Okusawa T, Fujita M, Nakamura J, Into T, Yasuda M, Yoshimura A, Shibata K (2004) Relationship between structures and biological activities of mycoplasmal diacylated lipopeptides and their recognition by toll-like receptors 2 and 6 . Infect Immun 72:1657-1665

42. Trueeb B, Braun R, Auray G, Kuhnert P, Summerfield A (2020) Differential innate immune responses induced by Mycoplasma hyopneumoniae and Mycoplasma hyorhinis in various types of antigen presenting cells. Vet Microbiol 240:108541

43. Mucha S, Ferrarini M, Moraga C, De Genova A, Guyon L, Tardy F, Rome S, Sagot MF, Zaha A (2020) Mycoplasma hyopneumoniae J elicits an antioxidant response and decreases the expression of ciliary genes in infected swine epithelial cells. Sci Rep 10:13707

44. Kobisch M, Blanchard B, Le Potier MF (1993) Mycoplasma hyopneumoniae infection in pigs: duration of the disease and resistance to reinfection. Vet Res 24:67-77

45. Villarreal I, Meyns T, Haesebrouck F, Dewulf J, Vranckx K, Calus D, Pasmans F, Maes D (2011) Effect of vaccination against Mycoplasma hyopneumoniae on the transmission of M. hyopneumoniae under field conditions. Vet J 188:48-52

46. Pieters M, Daniels J, Rovira A (2017) Comparison of sample types and diagnostic methods for in vivo detection of Mycoplasma hyopneumoniae during early stages of infection. Vet Microbiol 203:103-109

47. Chae C, Gomes-Neto JC, Segalés J, Sibila M (2020) Diversity of Mycoplasma hyopneumoniae strains. In: Book Mycoplasmas in Swine. Chapter 8. Editors: Maes D, Sibila M, Pieters M. ISBN 978-94-6379-796-2, Acco Publishers, Leuven Belgium. pp. 147-161

48. Djordjevic SP, Eamens GJ, Romalis LF, Nicholls PJ, Taylor V, Chin J (1997) Serum and mucosal antibody responses and protection in pigs vaccinated against Mycoplasma hyopneumoniae with vaccines containing 
a denatured membrane antigen pool and adjuvant. Aust Vet $J$ 75:504-511

49. Thacker EL, Thacker BJ, Boettcher TB, Jayappa H (1998) Comparison of antibody production, lymphocyte stimulation, and protection induced by four commercial Mycoplasma hyopneumoniae bacterins. J Swine Health Prod 6:107-112

50. Thacker EL, Thacker BJ, Kuhn M, Hawkins PA, Waters WR (2000) Evaluation of local and systemic immune responses induced by intramuscular injection of a Mycoplasma hyopneumoniae bacterin to pigs. Am J Vet Res 61:1384-1389

51. Sarradell J, Andrada M, Ramirez AS, Fernandez A, Gomez-Villamandos JC, Jover A, Lorenzo H, Herraez P, Rodriguez F (2003) A morphologic and immunohistochemical study of the bronchus-associated lymphoid tissue of pigs naturally infected with Mycoplasma hyopneumoniae. Vet Pathol 40:395-404

52. Woolley L, Fell S, Gonsalves J, Raymond B, Collins D, Kuit T, Walker M, Djordjevic S, Eamens G, Jenkins C (2014) Evaluation of recombinant Mycoplasma hyopneumoniae P97/P102 paralogs formulated with selected adjuvants as vaccines against mycoplasmal pneumonia in pigs. Vaccine 32:4333-4341

53. Marchioro S, Maes D, Flahou B, Pasmans F, Del Pozo SR, Vranckx K, Melkebeek V, Cox E, Wuyts N, Haesebrouck F (2013) Local and systemic immune responses in pigs intramuscularly injected with an inactivated Mycoplasma hyopneumoniae vaccine. Vaccine 31:1305-1311

54. Deeney AS, Maglennon GA, Chapat L, Crussard S, Jolivet E, Rycroft AN (2019) Mycoplasma hyopneumoniae evades phagocytic uptake by porcine alveolar macrophages in vitro. Vet Res 50:51

55. Borjigin L, Shimazu T, Katayama Y, Li M, Satoh T, Watanabe K, Kitazawa H, Roh S, Aso H, Katoh K, Uchida T, Suda Y, Nakajo SA, M, Suzuki K, (2016) Immunogenic properties of Landrace pigs selected for resistance to mycoplasma pneumonia of swine. Anim Sci J 87:321-329

56. Abbas A, Lichtman A, Pillai S (2016) Basic immunology: functions and disorders of the immune system (Abbas AK, Ed. 5th edition). St. Louis, Missouri, USA: Elsevier

57. Liang SC, Long AJ, Bennett F, Whitters MJ, Karim R, Collins M, Goldman SJ, Dunussi-Joannopoulos K, Williams CM, Wright JF (2007) An IL-17F/A heterodimer protein is produced by mouse Th17 cells and induces airway neutrophil recruitment. J Immunol 179:7791-7799

58. Jaffar Z, Ferrini ME, Herritt LA, Roberts K (2009) Cutting edge: lung mucosal Th17-mediated responses induce polymeric lg receptor expression by the airway epithelium and elevate secretory IgA levels. J Immunol 182:4507-4511

59. Jones HP, Simecka JW (2003) T lymphocyte responses are critical determinants in the pathogenesis and resistance to mycoplasma respiratory disease. Front Biosci 8:930-945

60. Maes D, Boyen F, Dellagostin O, Shao G, Haesebrouck F (2020) Vac cines and vaccination against Mycoplasma hyopneumoniae. In: Book Mycoplasmas in Swine. Chapter 11. Editors: Dominiek Maes, Marina Sibila, Maria Pieters. ISBN 978-94-6379-796-2, Acco Publishers, Leuven Belgium. pp: 207-228

61. Park C, Jeong J, Choi K, Chae C (2016) Efficacy of a new bivalent vaccine of porcine circovirus type 2 and Mycoplasma hyopneumoniae (FosteraTM PCV MH) under experimental conditions. Vaccine 34:270-272

62. Feng Z, Wei Y, Li G, Lu X, Wan X, Pharr G, Wang Z, Kong M, Gan Y, Bai F, Liu M, Xiong Q, Wu X, Shao G (2013) Development and validation of an attenuated Mycoplasma hyopneumoniae aerosol vaccine. Vet Microbiol 167:417-424

63. Feng Z, Shao G, Liu M, Wu X, Zhou Y, Gan Y (2010) Immune responses to the attenuated Mycoplasma hyopneumoniae 168 strain vaccine by intrapulmonic immunization in piglets. Agr Sci China 9:423-431

64. Michiels A, Arsenakis I, Boyen F, Krejci R, Haesebrouck F, Maes D (2017) Efficacy of one dose vaccination against experimental infection with two Mycoplasma hyopneumoniae strains. BMC Vet Res 13:274

65. Vranckx K, Maes D, Villarreal I, Chiers K, Pasmans F, Haesebrouck F (2012) Vaccination reduces macrophage infiltration in bronchus-associated lymphoid tissue in pigs infected with a highly virulent Mycoplasma hyopneumoniae strain. BMC Vet Res 8:24

66. Maes D, Deluyker H, Verdonck M, Castryck F, Miry C, Vrijens B, Verbeke W, Viaene J, de Kruif A (1999) Effect of vaccination against Mycoplasma hyopneumoniae in pig herds with an all-in/all-out production system. Vaccine 17:1024-1034
67. Goodwin RF, Hodgson RG, Whittlestone P, Woodhams RL (1969) Some experiments relating to artificial immunity in enzootic pneumonia of pigs. J Hyg (Lond) 67:465-476

68. Martelli P, Saleri R, Cavalli V, De Angelis E, Ferrari L, Benetti M, Ferrarini G, Merialdi G, Borghetti P (2014) Systemic and local immune response in pigs intradermally and intramuscularly injected with inactivated Mycoplasma hyopneumoniae vaccines. Vet Microbiol 168:357-364

69. Maes D, Segalés J, Meyns T, Sibila M, Pieters M, Haesebrouck F (2008) Control of Mycoplasma hyopneumoniae infections in pigs. Vet Microbiol 126:297-309

70. Meyns T, Dewulf J, de Kruif A, Calus D, Haesebrouck F, Maes D (2006) Comparison of transmission of Mycoplasma hyopneumoniae in vaccinated and non-vaccinated populations. Vaccine 24:7081-7086

71. Sibila M, Nofrarias M, Lopez-Soria S, Segalés J, Valero O, Espinal A, Calsamiglia M (2007) Chronological study of Mycoplasma hyopneumoniae infection, seroconversion and associated lung lesions in vaccinated and non-vaccinated pigs. Vet Microbiol 122:97-107

72. Munyaka P, Blanc F, Estelle J, Lemonnier G, Leplat JJ, Rossignol MN, Jardet D, Plastow G, Billon Y, Willing B, Rogel-Gaillard C (2020) Discovery of predictors of Mycoplasma hyopneumoniae vaccine response efficiency in pigs: 165 rRNA gene fecal microbiota analysis. Microorganisms 8:1151

73. Pieters M, Fano E, Pijoan C, Dee S (2010) An experimental model to evaluate Mycoplasma hyopneumoniae transmission from asymptomatic carriers to unvaccinated and vaccinated sentinel pigs. Can J Vet Res 74:157-160

74. Betlach AM, Fano E, VanderWaal K, Pieters M (2021) Effect of multiple vaccinations on transmission and degree of Mycoplasma hyopneumoniae infection in gilts. Vaccine 39:767-774

75. Fagan P, Djordjevic S, Chin J, Eamens G, Walker M (1997) Oral immunization of mice with attenuated Salmonella typhimurium aroA expressing a recombinant Mycoplasma hyopneumoniae antigen (NrdF). Infect Immun 65:2502-2507

76. Chen AY, Fry S, Forbes-Faulkner J, Daggard G, Mukkur T (2006) Evaluation of the immunogenicity of the P97R1 adhesin of Mycoplasma hyopneumoniae as a mucosal vaccine in mice. J Med Microbiol 55:923-929

77. Chen AY, Fry S, Forbes-Faulkner J, Daggard G, Mukkur T (2006) Comparative immunogenicity of $M$. hyopneumoniae NrdF encoded in different expression systems delivered orally via attenuated STyphimurium aroA in mice. Vet Microbiol 114:252-259

78. Okamba F, Moreau E, Cheikh Saad B, Gagnon C, Massie B, Arella M (2007) Immune responses induced by replication-defective adenovirus expressing the C-terminal portion of the Mycoplasma hyopneumoniae P97 adhesin. Clin Vaccine Immunol 14:767-774

79. Zou H, Liu X, Ma F, Chen P, Zhou R, He Q (2011) Attenuated Actinobacillus pleuropneumoniae as a bacterial vector for expression of Mycoplasma hyopneumoniae P36 gene. J Gene Med 13:221-229

80. Roques E, Girard A, Gagnon C, Archambault D (2013) Antibody responses induced in mice immunized with recombinant adenovectors expressing chimeric proteins of various porcine pathogens. Vaccine 31:2698-2704

81. Wang Y, Wang J, Zhou M, Liu P, Zhang E, Li Y, Lin J, Feng Z (2019) Yand Q (2019) Mucosal and systemic immune responses induced by intranasal immunization of recombinant Bacillus subtilis expressing the P97R1, P46 antigens of Mycoplasma hyopneumoniae. Biosci Rep. 39:BSR20191126

82. Menon S, Wannemuehler M, Mahairas G, Minion FC (2002) Mycobacterial ESAT-6 protein enhances mouse IFN- $\gamma$ responses to Mycoplasma hyopneumoniae P71 protein. J Interf Cytok Res 22:807-813

83. Conceição F, Moreira A, Dellagostin O (2006) A recombinant chimera composed of R1 repeat region of Mycoplasma hyopneumoniae P97 adhesin with Escherichia coli heat-labile enterotoxin B subunit elicits immune response in mice. Vaccine 24:5734-5743

84. Barate A, Cho Y, Truon Q, Hahn T (2014) Immunogenicity of IMS 1113 plus soluble subunit and chimeric proteins containing Mycoplasma hyopneumoniae P97 C-terminal repeat regions. FEMS Microbiol Lett 352:213-220

85. Virginio V, Bandeira N, Leal F, Lancelotti M, Zaha A, Ferreira H (2017) Assessment of the adjuvant activity of mesoporous silica nanoparticles in recombinant Mycoplasma hyopneumoniae antigen vaccines. Heliyon 3:e00225 
86. De Oliveira NR, Jorge S, Gomez CK, Rizzi C, Dias Pacce V, Collares F, Monte GL, Dellagostin O (2017) A novel chimeric protein composed of recombinant Mycoplasma hyopneumoniae antigens as a vaccine candidate evaluated in mice. Vet Microbiol 201:146-153

87. Chen Y, Wang S, Yang W, Chen Y, Lin H, Shiuan D (2003) Expression and immunogenicity of Mycoplasma hyopneumoniae heat shock protein antigen p42 by DNA vaccination. Infect Immun 71:1155-1160

88. Minion FC, Menon S, Mahairas G, Wannemuehler M (2003) Enhanced murine antigen-specific gamma interferon and immunoglobulin G2a responses by using mycobacterial ESAT-6 sequences in DNA vaccines. Infect Immun 71:2239-2243

89. Chen AY, Fry S, Daggard G, Mukkur K (2008) Evaluation of immune response to recombinant potential protective antigens of Mycoplasma hyopneumoniae delivered as cocktail DNA and/or recombinant protein vaccines in mice. Vaccine 26:372-378

90. Galli V, Simionatto S, Marchioro S, Fisch A, Gomes C, Conceição F, Dellagostin O (2012) Immunisation of mice with Mycoplasma hyopneumoniae antigens P37, P42, P46 and P95 delivered as recombinant subunit or DNA vaccines. Vaccine 31:135-140

91. Virginio V, Gonschoroski T, Paes J, Schuck D, Zaha A, Ferreira H (2014) Immune responses elicited by Mycoplasma hyopneumoniae recombinant antigens and DNA constructs with potential for use in vaccination against porcine enzootic pneumonia. Vaccine 44:5832-5838

92. Stevens T, Bossie A, Sanders V, Fernandez-Botran R, Coffman R, Mosmann T, Vitetta E (1998) Regulation of antibody isotype secretion by subsets of antigen-specific helper T cells. Nature 334:255-258

93. Fairbairn L, Kapetanovic R, Sester DP, Hume DA (2011) The mononuclear phagocyte system of the pig as a model for understanding human innate immunity and disease. J Leukoc Biol 89:855-871

94. Fagan P, Walker M, Chin J, Eamens G, Djordjevic S (2001) Oral immunization of swine with attenuated Salmonella typhimurium aroA SL3261 expressing a recombinant antigen of Mycoplasma hyopneumoniae (NrdF) primes the immune system for a NrdF specific secretory lgA response in the lungs. Microb Pathog 30:101-110

95. Shimoji Y, Oishi E, Muneta Y, Nosaka H, Mori Y (2003) Vaccine efficacy of the attenuated Erysipelothrix rhusiopathiae YS-19 expressing a recombinant protein of Mycoplasma hyopneumoniae P97 adhesin against mycoplasmal pneumonia of swine. Vaccine 21:532-537

96. Ogawa Y, Oishi E, Muneta Y, Sano A, Hikono H, Shibahara T, Yagi Y, Shimoji Y (2009) Oral vaccination against mycoplasmal pneumonia of swine using a live Erysipelothrix rhusiopathiae vaccine strain as a vector. Vaccine 27:4543-4550

97. Okamba F, Arella M, Music N, Jia J, Gottschalk M, Gagnon C (2010) Potential use of a recombinant replication-defective adenovirus vector carrying the C-terminal portion of the P97 adhesin protein as a vaccine against Mycoplasma hyopneumoniae in swine. Vaccine 28:4802-4809

98. King K, Faulds D, Rosey E, Yancey R Jr (1997) Characterization of the gene encoding Mhp1 from Mycoplasma hyopneumoniae and examination of Mhp1's vaccine potential. Vaccine 15:25-35

99. Okada M, Asai T, Ono M, Sakano T, Sato S (2000) Protective effect of vaccination with culture supernate of $M$. hyopneumoniae against experimental infection in pigs. J Vet Med B 47:527-533

100. Okada M, Asai T, Ono M, Sakano T, Sato S (2000) Cytological and immunological changes in bronchoalveolar lavage fluid and histological observation of lung lesions in pigs immunized with Mycoplasma hyopneumoniae inactivated vaccine prepared from broth culture supernate. Vaccine 18:2825-2831

101. Chen J, Liao C, Mao S, Weng C (2001) A recombinant chimera composed of repeat region RR1 of Mycoplasma hyopneumoniae adhesin with Pseudomonas exotoxin: in vivo evaluation of specific lgG response in mice and pigs. Vet Microbiol 80:347-357

102. Lee SH, Lee S, Chae C, Ryu D-Y (2014) A recombinant chimera comprising the $\mathrm{R} 1$ and $\mathrm{R} 2$ repeat regions of $M$. hyopneumoniae $\mathrm{P} 97$ and the N-terminal region of A. pleuropneumoniae Apxlll elicits immune responses. BMC Vet Res. 10:43

103. Lin J, Pan M, Liao C, Weng C (2002) In vivo and in vitro comparisons of spray-drying and solvent-evaporation preparation of microencapsulated Mycoplasma hyopneumoniae for use as an orally administered vaccine for pigs. Am J Vet Res 63:1118-1123

104. Lin J, Weng C, Liao C, Yeh K, Pan M (2003) Protective effects of oral microencapsulated Mycoplasma hyopneumoniae vaccine prepared by co-spray drying method. J Vet Med Sci 65:69-74

105. Matthijs A, Auray G, Jakob V, García-Nicolás O, Braun R, Keller I, Bruggman R, Devriendt B, Boyen F, Guzman C, Michiels A, Haesebrouck F, Collin N, Barnier-Quer C, Maes D, Summerfield A (2019) System immunology characterization of novel vaccine formulations for Mycoplasma hyopneumoniae bacterins. Front Immunol 10:1087

106. Matthijs A, Auray G, Boyen F, Michiels A, Garcia-Nicolas O, Barut GT, Barut G, Barnier-Quer C, Jakob V, Collin N, Devriendt B, Summerfield A, Haesebrouck F, Maes D (2019) Efficacy of three innovative bacterin vaccines against experimental infection with Mycoplasma hyopneumoniae. Vet Res 50:91

107. Meens J, Bolotin V, Frank R, Böhmer J, Gerlach GF (2010) Characterization of a highly immunogenic Mycoplasma hyopneumoniae lipoprotein Mhp366 identified by peptide-spot array. Vet Microbiol 142:293-302

108. Pendarvis K, Padula MP, Tacchi JL, Petersen AC, Djordjevic SP, Burgess SC, Minion FC (2014) Proteogenomic mapping of Mycoplasma hyopneumoniae virulent strain 232. BMC Genomics 15:576

109. Neutra MR, Kozlowski PA (2006) Mucosal vaccines: the promise and the challenge. Nat Rev Immunol 6:148-158

110. Aoshi T (2017) Modes of action for mucosal vaccine adjuvants. Viral Immunol 30:463-470

111. Figueras Gourgues S, Fano E, Alegre Sabaté A, López Grasa E, Hernández Caravaca I, García Vázquez FA, Rodríguez Vega V, Garcia-Morante B (2020) Assessment of nebulization technology for gilt exposure to Mycoplasma hyopneumoniae as an acclimation strategy. J Swine Health Prod 28:294-301

112. Wilson HL, Obradovic MR (2015) Evidence for a common mucosal immune system in the pig. Mol Immunol 66:22-34

113. Fu T, Ulmer JB, Caufield MJ, Deck RR, Friedman A, Wang S, Liu X, Donnelly JJ, Liu MA (1997) Priming of cytotoxic T lymphocytes by DNA vaccines. Requirement for professional antigen presenting cells and evidences for antigen transfer from myocytes. Mol Med 3:362-371

114. Bastola R, Noh G, Keum T, Bashyal S, Seo JE, Choi J, Oh Y, Cho Y, Lee S (2017) Vaccine adjuvants: smart components to boost the immune system. Arch Pharm Res 40:1238-1248

115. Villarreal I, Maes D, Meyns T, Gebruers F, Calus D, Pasmans F, Haesebrouck F (2009) Infection with a low virulent Mycoplasma hyopneumoniae isolate does not protect piglets against subsequent infection with a highly virulent M. hyopneumoniae isolate. Vaccine 27:1875-1879

\section{Publisher's Note}

Springer Nature remains neutral with regard to jurisdictional claims in published maps and institutional affiliations. 